\title{
Türkiye’de Bireysel Gelir Dağılımlarının Stokastik Baskınlık Kriteri ile Bölgelerarası Değerlendirmesi
}

\author{
Neslihan FIDAN KEÇECI*
}

ÖZ

Ülkemizde gelir dağılımı analizi için kullanılan en yaygın yaklaşımlar yüzde paylar ve Lorenz Eğrisi üzerinden hesaplanan Gini katsayısıdır. Parametrik olmayan bir yaklaşım olarak stokastik baskınlık, klasik yaklaşımlardan farklı bir yorumla gelir dağılımları arasında mikro düzeyde karşılaştırma sağlamaktadır. Lorenz eğrisinin hesaplama süreci stokastik baskınlık kriteri ile direkt ilişkilidir. İkinci Dereceden Stokastik Baskınlık (SSD) kriteri günümüzde daha çok finans alanında yapılan analizlerde kullanılırken Lorenz Eğrisi gelir dağılımı eşitsizliği üzerine yapılan analizlerde kullanılmaktadır. Bu çalışmada, Türkiye'de bölgeler arası gelir dağılımının keşfedilmesi amacıyla, TÜİK'in Gelir ve Yaşam Koşulları Araştırması 2007-2016 yılları arası anketleri İstatistiki Bölge Birimleri Sınıflamasına göre Düzey-1'e göre incelenmiştir. Bölgeler arası gelir dağılımı farklılıkları SSD kriteri ile karşılaştırılmakta ve bireysel gelirlerin birbirlerine baskınlığı incelenmektedir. Bireysel gelir dağılımlarının karşılaştırmalarından elde edilen sonuçlara göre; İstanbul ve Doğu Karadeniz diğer bölgelere en fazla sayıda baskınlık sağlayan bölgelerdir. Güney Doğu Anadolu bölgesinin hiçbir bölgeye karşı bireysel gelir dağılımları açısından baskın olmayan bir bölge olduğu söylenebilmektedir. Dolayısıyla SSD kriteri açısından değerlendirildiğinde gelir eşitsizliğinin, özellikle diğer bölgelere göre fazla sayıda baskınlık alabilen bölgeler ile baskınlık alamayan bölgeler arasında büyük boyutta olduğu söylenebilir. Çalışmada elde edilen bulguların bölgelere göre politika geliştirme sürecinde karar alıcılar açısından değerlendirilebilir nitelikte olduğu düşünülmektedir.

Anahtar Kelimeler: Stokastik sıralama, İkinci dereceden stokastik baskınlık, Gelir dağılımı, Gelir eşitsizliği, Lorenz eğrisi

JEL Sinıflandırması: E01, N34, O1

\section{Regional Evaluation of Individual Income Distribution in Turkey with Stochastic Dominance Criteria}

\begin{abstract}
The most common approaches used for income distribution analysis are the percentile shares and the Gini coefficient calculated on Lorenz curve. As another nonparametric approach, stochastic dominance provides different interpretation opportunities for comparison between income distributions. While the second order stochastic dominance criterion is a term mostly used in finance; Lorenz Curve is used in the analysis of income distribution inequality. In order to be discovered in terms of regional income distribution in Turkey, the Turkey Statistics Institute Survey of Income and Living Conditions survey years 2007-2016 were used. According to the comparison of individual income distributions among regions, while the regions that provide the highest number of dominance are Istanbul and East Blacksea, South East Anatolia region cannot second order stochastically dominate any region. Therefore, when considered in terms of the second order stochastic dominance criteria, it can be said that the income inequality is large, especially between regions that can dominate other regions with a large number and regions that cannot. The results obtained are considered to be evaluable in the policy development process by regions.
\end{abstract}

Keywords: Stochastic ordering, Second order stochastic dominance, Income distribution, Income inequality, Lorenz curve

JEL Classification: E01, N34, O1

Geliş Tarihi / Received: 20.11.2020 Kabul Tarihi / Accepted: 27.02.2021 Doi: 10.17541/optimum. 828768

\footnotetext{
* Dr. Öğr. Üyesi, İstanbul Üniversitesi, İşletme Fakültesi, İşletme Bölümü, neslihan @istanbul.edu.tr, ORCID: 00000003-3007-9963
} 


\section{GİRIŞ}

Bir ekonomide belirli bir dönemde üretilen mal ve hizmetlerin toplamına gelir denir ve gelir, toplam hasıla olarak da bilinir. Gelir, hanehalkı açısından ise belirli bir zaman aralığında üretime yapılan katkı karşılığında sağlanan değerlerin toplamı olarak tanımlanabilir. Aynı zamanda kira, faiz veya kar da hanehalkı geliri olarak sayılabilir. Bir ülkede belirli zaman aralığında sağlanan gelirin fertler, hane halkları veya üretim faktörleri arasında bölünmesi ise Gelir Dağılımıdır (TÜIKK, 2018). Hanelerin gelir dağılımından hareketle bireyler arasındaki gelir farklılıkları gelirin sosyal açıdan da bir göstergesi olarak ele alınabilir. Bunun için hane halkı toplam gelirinin bireysel gelirlere dönüştürülmesi gerekir. Bir hanedeki fertler, referans kişi 14 yaşını aşan yetişkinler ve 14 yaş altı kişiler olmak üzere OECD ölçeği ile ağırlıklandırılarak, yıllık toplam hanehalkı toplam geliri bireysel gelirlere dönüştürülmektedir. Böylece eşdeğerlik ölçeği ile eşdeğer bireylerin ya da farklı büyüklüklerdeki hanelerin gelirleri de karşılaştırılabilir olmaktadir.

İnsanlar hukuki açıdan eşit sayılmalarına rağmen neredeyse tüm ülkelerde gelirleri açısından eşitlik sağlanamamaktadır. Dünyadaki bazı ülkeler giderek zenginleşirken bazı ülkeler ise daha fakir hale gelmektedir. Gelir dağılımının belirlenmesi devletleri gelir eşitsizliğine yönelik politikalar geliştirmeye teşvik etmektedir. Gelir dağılımı eşitsizliği, nüfusun belirli bir diliminin gelirden aldığı pay ile aynı orandaki bir başka diliminin aldığı pay arasındaki farklılığı göstermektedir. Eşdeğer hanehalkı kullanılabilir gelirleri ile elde edilen gelir dağılımı eşitsizliği genellikle yüzdelik paylar ve Gini katsayısı ile değerlendirilebilmektedir. Yüzdelik paylar ile değerlendirmelerde, hanehalkı gelirleri genellikle beş ayrı gelir düzeyine ayrılarak sıralanır ve her bir gelir düzeyinin ortalama geliri dikkate alınır (Filiztekin ve Çelik, 2010). Böylece her bir grubun toplam gelirden aldıkları pay elde edilerek hakkında bilgi sağlanmış olur. Özellikle 1970'lerden sonra daha çok anılan Gini katsayısı ise her ne kadar gelir eşitsizliğinin geleneksel bir ölçüsü olarak daha iyi tasarlanmış olsa da dağılımlar hakkında eksik ve yanıltıcı bilgi verdiği ve sağladığ 1 faydalı bilginin yetersizliği konusunda birtakım eleştirilere maruz kalmıştır (Atkinson, 1970; Dasgupta, Sen ve Starrett, 1973; Rothschild ve Stiglitz, 1973; Sen, 1973). Özdemir, (2019) Lorenz eğrisi ve Gini katsayısı katsayısının da içinde bulunduğu altı farklı gelir eşitsizliği ölçüm yöntemi hakkında bilgilendirici bir çalışma yapmıştır. Bu çalışmasında dünyada gelir dağılımını ölçmek için genel kabul görmesine rağmen, Gini katsayısının çok güvenilir sonuçlar ürettiğini söylemenin güç olduğunu “Türkiye ile ABD'nin Gini katsayısı birbirine çok yakın değerler aldığı” örneğini vererek belirtmektedir.

Bölgesel gelir dağılımı ise, farklı bölgelerde yaşayan bireylere göre gelirin dağılımı olarak ifade edilmektedir (Alabaş, 2015). Ülkeler arası farklı ekonomik sistemler nedeniyle ortaya çıkan gelir farklılıkları aynı zamanda bir ülkenin bölgeleri arasında da görülebilmektedir. Sosyal ve ekonomik yaşamı etkileyen bu konu dünyada birçok iktisatçı tarafından araştırılmıştır. Dünyanın pek çok ülkesinde ve ülkemizde araştırmalar sonucu elde edilerek yayınlanan istatistiklerden de anlaşılabileceği gibi yüksek seviyelerde gelir farklılıklarının, yok edilemese de azaltılması ve çözümlenmesi gereken problem olarak görülmesi aşikardır. Bölgelere göre gelişmişlik düzeylerindeki farklılıklar da gelir eşitsizliği sorununu ortaya çıkarmaktadır. Dolayısıyla gelişmişlik göstergesi olarak gelir eşitsizliği ölçümünün sağlıklı yapılması gerekmektedir. Bölgeler arası gelir eşitsizliğinin birçok ve birbirinden oldukça farklı nedenleri olabilirken, gelir eşitsizliğin de sebep olduğu pek çok durum bulunmaktadır. Örneğin, bölgesel gelir eşitsizliğinin önemli birer sonucu işsizlik ve göçtür. Bireylerin ekonomik refahının yükseltilebilmesi amacıyla geliştirilecek politikalar için her bir bölgenin kendi iç dinamiklerini dikkate alan analizler yapılması gerekmektedir. Zamanla anlaşılmıştır ki, gelir eşitsizliği ekonomik büyümeyle ve endüstriyel ekonomiye geçişle kendiliğinden ortadan kalkmamakta, dolayısıyla devletler ve uluslararası örgütlerin aktif çalışmalarıyla çözüm aramayı gerektirmektedir. Gelir eşitsizliğinin bir başka boyutu ise eğitimde fursat eşitsizliği yaratmasıdır. Düşük gelirli ancak yetenekli bireylerin sahip oldukları kapasiteyi yansıtacak eğitimi 
alamamaları, çalışma yaşamlarında yine düşük gelire sahip olarak devam etmelerine neden olabildiği için gelir eşitsizliğini bir sonraki nesile aktarmalarına yol açmaktadır. Bu geçişler ülkenin üretkenliğinin azalmasına ve daha düşük bir reel büyümeye sebep olmaktadır (Filiztekin ve Çelik, 2010).

Gini katsayısı ve yüzdelik paylar gibi verilerin dağılımı hakkında özet bilgi ile karşılaştırma sağlayan ölçüler dışında mikro düzeyde yani daha kapsamlı karşılaştırmalar sağlayacak ölçümlere ihtiyaç duyulmaktadır. Bu çalışmada, bölgelerarası gelir dağılımlarının birbirlerine göre farklılıkları stokastik baskınlık kavramı tanımına dayanarak mikro düzeyde karşılaştırılmaktadır. Öncelikle literatür bölümünde çoğunun ortak özelliği, uygulamalarda istatistiksel dağılımın teorisine ilişkin varsayımları göz ardı edebilen bir kriter olarak stokastik baskınlığı dikkate alan uluslararası ve ulusal çalışmalara yer verilmektedir. Daha sonra Birinci ve İkinci Derece Stokastik Baskınlık ${ }^{1}$ kriterlerine ilişkin formülasyonlar ve SSD'nin Lorenz eğrisi ile denkliği verilmektedir. Ardından üçüncü bölümde Türkiye'de gelir dağılımının bölgesel açıdan keşfedilmesi amacıyla önce geçmiş ulusal çalışmalara ve ardından da SSD kriteri ile analize geçilmektedir. Analizde Türkiye İstatistik Kurumu (TÜIK)'in Gelir ve Yaşam Koşulları Araştırması anketlerinden Eşdeğer hanehalkı kullanılabilir fert geliri dağılımları kullanılarak, 2007-2016 yılları için Türkiye İstatistiki Bölge Birimleri Sınıflaması (IBBS)'na göre Düzey-1 bölgelerinin bireysel gelir dağılımlarının birbirlerine üstünlükleri karşılaştırılmaktadır.

\section{LITERATÜR}

Gelir eşitsizliği ülkelerin üzerine çalışması gerektiği en önemli konulardan biri iken, bu konuda yapılan akademik çalışmalar da alanda yerini bulmaktadır. Ülkemizde gelir dağılımı üzerine pek çok çalışma bulunmaktadır. Türkiye'de bölgesel gelir dağılımı eşitsizliği problemini ele alan çalışmalara ayrıca son bölümde değinilmektedir. Bu bölümde, özellikle bu çalışmanın odak noktasını oluşturan Stokastik Baskınlık kriterini kullanan çalışmalara yer verilmektedir.

Uluslararası yazında stokastik baskınlık kriteri ile gelir dağılımlarını karşılaştıran ilk çalışmalara ulaşmak oldukça güçtür. Geriye doğru gidildiğinde gelir eşitsizliğiyle ilgili ilk karşılaşılan çalışmalar arasında Atkinson (1970) ve onu takip eden Yitzhaki (1982) ve Shorrocks (1983)'e ulaşılmaktadır. Atkinson (1970), Hadar ve Russel (1969) ile Hanoch and Levy (1969)'ye referans vererek eşitsizliğin ölçümünde tam sıralamayı dikkate almakta ve Lorenz eğrisi ile Stokastik Baskınlık arasındaki ilişkiye değinmektedir. Atkinson (1970), Dasgupta, Sen ve Starrett (1973), Rothschild ve Stiglitz (1973) ve Sen (1973) çalışmalarında Gini katsayısının gelir dağılımlarına ilişkin özet bilgi içerdiklerini vurgulamaktadırlar. Dorfman (1979) hem kesikli hem de sürekli gelir dağılımları için geçerli, Gini katsayısı üzerine iyi tanımlanmış bir formülasyon sunmuştur. Yitzhaki (1982), belirsizlik içeren durumlara ortalama-varyans gibi özet istatistiklerle yorum kolaylığından bahsederken Stokastik Baskınlığın ortalama-varyans'a nazaran daha tutarlı sonuçlar verebildiğine değinmiş ve Gini katsayısıyla ilişkilendirmiştir. Yitzhaki (1983) ise Gini katsayısının Lorenz eğrisi ile geometrik olarak sunulabildiğini belirtmiştir. Ancak Atkinson (1970)'da gelir dağılımlarıyla ilgili yapılan değerlendirmelerin iyi ifade edilemediği belirtilmekte ve parametrik Gini endeks ile baskınlık kriteri karşılaş̧ırılmaktadır. Shorrocks (1983) genelleştirilmiş Lorenz eğrileri arasında baskınlık arayarak sıralamanın nasıl uygulanabileceği üzerinde durmaktadır ve farklı ülkelerin gelir dağılımlarını kullanarak bir uygulama sunmaktadır.

\footnotetext{
1 Çalışmanın bu kısmından sonra FSD (First order Stochastic Dominance) ve SSD (Second order Stochastic Dominance) kısaltmalarılla yer almıştır.
} 
Foster ve Shorrocks (1988), sıradan Lorenz eğrisinin ilgili dağılımın ortalaması ile ölçeklendirilmesinden oluşturulan genelleştirilmiş Lorenz eğrileri, yoksulluk ölçümü ve refah arasındaki ilişki ele alınarak, genelleştirilmiş Lorenz baskınlığının SSD'ye denk olduğu gösterilmektedir. Bishop, Chakraborti ve Thistle (1989), 1969 ve 1979 yılları arası için onluk eşit parçalarla Amerika hanehalkı sıralı gelir dağılımlarını karşılaştırmışlar ve 1979 yılı gelir dağılımının 1969 yılına baskın olduğu sonucuna varmışlardır. Ayrıca, genelleştirilmiş Lorenz eğrileri için asimptotik olarak dağılımdan bağımsız istatistiksel çıkarımlarla elde edilen sonuçların SSD'yi test etmek için uygulanabilir olduğunu da belirtmişlerdir. Bishop, Formby ve Smith (1991) ise uluslararası gelir eşitsizliğine ilişkin çalışmalarında 9 ülkenin gelir dağılımını Lorenz baskınlık testi ile ikişerli değerlendirmişlerdir. Anderson (1996), genelleştirilmiş Lorenz eğrilerinin kullanımından kaçınarak, farklılıkları orijinal dağılımlar üzerinden karşılaştırmak için parametrik olmayan yöntemleri kullanmaktadır. Ayrıca ilgili çalışmada, gelir dağılımları arasındaki farkların araştırılması için birinci, ikinci ve üçüncü dereceden olmak üzere, üç stokastik baskınlık kriteri üzerine parametrik olmayan yeni bir test de önerilmektedir.

Ferreira ve Litchfield (1996) gelir dağılımı karşılaştırmalarında geleneksel yöntemlere alternatif ve tamamlayıcı bir yaklaşım olarak stokastik baskınlığı önermekte, ortalama ile ölçeklendirilmiş Lorenz baskınlığın ile SSD denkliğini dile getirmektedir. Bu çalışmalarında, dağılımlar arasındaki eşitsizliğin açık bir ifadesi olarak Lorenz baskınlığı işaret etmişler ve Brezilya'da, gelirlerdeki büyümeye rağmen yoksulluğun da arttığı sonucuna vardıkları bir uygulama çalışması yapmışlardır (Ferreira ve Litchfield, 1996). Maasoumi ve Heshmati (2000) İsveç nüfusunun çeşitli alt grupları için farklı yıllardaki gelir dağılımları arasında stokastik baskınlıkları araştırmış ve ülkenin mevcut refah politikalarının tutarlığ bulunmuşlardır. Davidson ve Duclos (2000) gelir dağılımlarını stokastik baskınlıklarını belirlemek için kullanılan tahmin edicilerin asimptotik örnekleme dağılımını çıkarmışlardır. Uygulamalarında, Lüksemburg Gelir Çalışması veri tabanlarından alınan dört ülkeye ait gelir dağılımları arasındaki stokastik baskınlık karşılaştırmışlarıyla bu ülkelere ait eşitsizlik, refah ve yoksulluk düzenleri tahmin edilmeye çalışılmıştır.

Le Breton, Michelangeli ve Peluso (2012), çalışmalarında belirli bir gelir eşiğinde Gastwirth'in ayrımcılık endeksi ve bir grafik özet olarak ikinci derece ayrımcılık eğrisi arasındaki bağıntının, Genelleştirilmiş Lorenz baskınlığı ile SSD arasındaki denkliğin bir genelleştirmesi olduğuna değinmektedirler. Mehdi (2019) ise, OECD'nin içinde Türkiye'nin de içinde bulunduğu bir indeksle ölçülen refah düzeyinin testi için stokastik baskınlıktan faydalanmıştır. Mehdi (2020)'de ise mevcut testler üzerine önerdiği stokastik baskınlık testlerini Kanada hanehalkı gelir dağılımlarına uygulayarak kadın ve erkekler arasındaki yoksulluk sıralamasına ait sonuçlar elde etmiştir.

SSD kriteri ile gelir eşitsizliğini ele alan yalnızca iki ulusal çalışmaya ulaşılabilmektedir. Eşitsizlik ölçüleri arasında alternatif bir yaklaşım olarak stokastik baskınlık testlerini kullanan Doğanoğlu ve Gülcü (2001), çalışmalarında baskınlık formülasyonuna yer vermektedirler. Geleneksel katsayıların anlamsızlaştığı durumlarda, dağılımlarının farklı katmanlardaki farklı duyarlılıkları için, bir uçtan diğer bir uca karşılaştırmalarının stokastik baskınlık kriteri ile yapılmasını önermektedirler. İkinci bir ulusal çalışma olarak ise Aran vd. (2010)'de 2003 ve 2006 yılları için Türkiye'deki yoksulluk ve eşitsizlik düzeylerindeki genel değişiklikleri incelemekte ve tüketim dağılımının zamanla değişimi üzerine analiz yapmaktadırlar. FSD ve SSD kriterlerinden yoksulluk sınır değerinin değiştiği durumlarda yoksulluk ölçütünün hassasiyetini test etmek için faydalanmaktadırlar. SSD kriterini, yoksulluk açığı eğrileri olarak tanımladıkları tüketim dağılımlarının yıllara göre kıyaslamasında kullanmışlardır. Sonuçta kentsel alanlarda 2006 yılının 2003 yılına baskın olduğunu, kırsal alanlarda ise yıllar arasında bir baskınlık söz konusu olmadığını belirtmektedirler. 


\section{STOKASTIKK BASKINLIK}

Stokastik baskınlık, bir rastlantı değişkeninin dağılımını gözetmeden dağılımı oluşturan değerlerin tamamını dikkate alan bir kriterdir (Hanoch ve Levy, 1969). FSD ve SSD kriterlerini ilk ele alanların Quirk ve Saposnik (1962), Hadar ve Russell (1969) ve Hanoch ve Levy (1969) olduğu bilinmektedir. Teorik olarak stokastik baskınlık, tercih edilen bir beklentinin birikimli dağılım değerinin, ikinci tercihin birikimli dağılımını hiçbir zaman aşmaması durumudur. Stokastik baskınlık tanımı aynı zamanda FSD tanımıdır (Hadar ve Russell, 1969). Dolayısıyla FSD ve SSD tanımları buna bağlı olarak aşağıda verilmektedir. Literatürde yüksek dereceden stokastik baskınlık tanımlarını da bulmaktadır ancak bu çalışmada değinilmemektedir.

\subsection{Birinci Derece Stokastik Baskınlık (FSD)}

Bir $x$ raslantı değişkeninin tüm gerçel değerleri $(x \in \mathcal{R})$ için $f(x)$ olasılık fonksiyonunu ve $F(x)=\int_{-\infty}^{x} f(t) d t$ olarak verilen kümülatif dağılımı dikkate alalım. $f$ ve $g$ gibi herhangi iki olasılık dağılımları tüm $x \in \mathcal{R}$ değerleri için;

$$
\boldsymbol{G}(\boldsymbol{x}) \geq \boldsymbol{F}(\boldsymbol{x})
$$

koşulunu sağlıyorlarsa " $f g$ 'ye birini derece stokastik baskındır" denir ve

$$
f \geqslant_{1} g
$$

ile gösterilir. Bu tanıma göre, $x$ 'in tüm mümkün değerleri için $f$ 'in beklenen faydası $g$ 'nin beklenen faydasından küçük değilse $f g$ 'ye birinci derece stokastik baskındır (Hanoch ve Levy, 1969). FSD kavramı basitçe "stokastik baskınlık" olarak da bilinmektedir.

\section{2 İkinci Derece Stokastik Baskınlık (SSD)}

Eğer tüm $x \in \mathcal{R}$ değerleri için

$$
\int_{-\infty}^{x} G(t) d t \geq \int_{-\infty}^{x} F(t) d t
$$

koşulu sağlanıyorsa " $f g$ 'ye ikinci derece stokastik baskındır" denir ve

$$
f \geqslant_{2} g
$$

ile gösterilir (Hadar and Russel, 1969). Bir raslantı değişkeni olan $x$ 'in bir eşik değer olarak $\eta$ hedefi için SSD ilişkisi tüm $\eta \in \mathcal{R}$ değerleri için

$$
\boldsymbol{E}\left([\boldsymbol{\eta}-\boldsymbol{f}]_{+}\right) \leq \boldsymbol{E}\left([\boldsymbol{\eta}-\boldsymbol{g}]_{+}\right)
$$

olarak tanımlanır, burada $[\eta-f]_{+}=\max (0, \eta-f)$ 'dir. Bu aynı zamanda konkav bir $u(x)$ fayda fonksiyonu için $E[u(g)] \leq E[u(f)]$ demektir. Bu durumda $f$ dağılımı $g$ dağılımına göre daha tahmin edilebilir veya daha az risk içerir şeklinde yorumlanır. Atkinson (1970), gelir dağılımlarını karşılaştırmak için sürekli dağılımların özelliklerinden faydalanarak SSD’yi uygulamaktadır. Dolayısıyla herhangi bir gelir dağılımının bir başka gelir dağılımına ikinci dereceden stokastik anlamda baskın olması, o dağılımın diğer gelir dağılımından daha baskın olduğu şeklinde de ifade edilebilir. 


\subsection{Lorenz Ĕgrisi ve SSD’nin Denkliği}

Max O. Lorenz 1905'te yayınlanan makalesinde gelir ya da servetin nüfusa dağılımı için çok temel bir yol önerir: 'Eksenlerden birine nüfusun kümülatif yüzdelerini en fakirden en zengine doğru, diğerine de nüfusun bu yüzdelerinin sahip olduğu toplam servetin yüzdelerini yerleştirerek grafiğini çizin.' (Lorenz, 1905). Böylece grafiğin dik ekseninde gelirin kümülatif payları, yatay ekseninde ise nüfusun kümülatif payları yüzdelik olarak gösterilmiş olur. Dolayısıyla artık yüzde noktalarını birleştiren eğri bir karenin köşegeni ile uç noktalarında tamamlanır ve bu eğri Lorenz eğrisi olarak anılmaktadır.

Grafik üzerinde bu eğrinin tamamlandığı noktaya orijinden çizilen doğru, gelirle nüfus arasında eşit dağılım söz konusu olduğunda elde edilecek durumu gösterir. Lorenz eğrisi olarak köşegenden uzaklaştıkça, gelir dağılımındaki eşitsizliğin de arttığı aşikardır. Genel olarak nüfus yüzdelerinin milli gelirden aldığı servet farklı olduğundan Lorenz Eğrisi tam eşitlik doğrusunun altında oluşmaktadır. 1914'te ise İtalyan istatistikçi Gini, Lorenz eğrisi ile ilişkilendirerek daha sonra adı ile anılan Gini konsantrasyon indeksini geliştirmiştir (Giorgi ve Gigliarano, 2017).

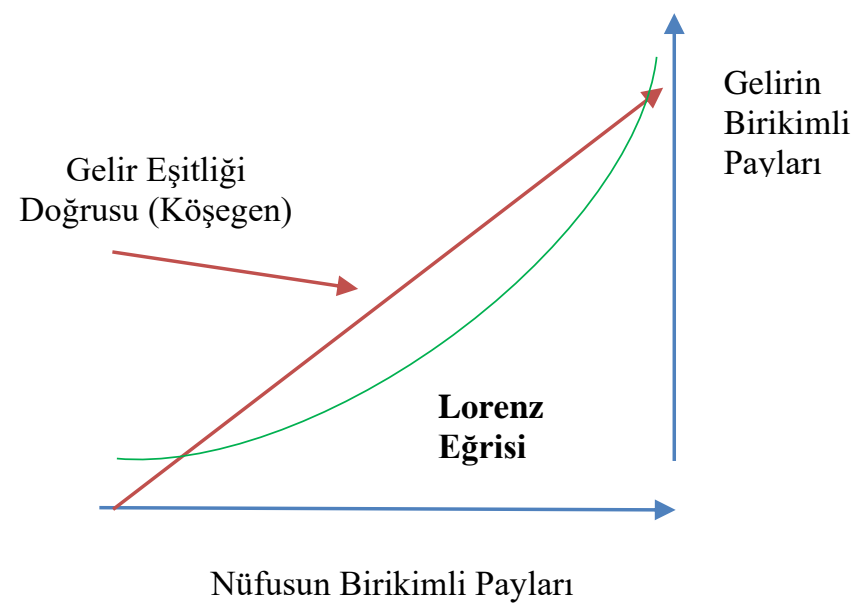

Şekil 1: Lorenz Eğrisi

Gini katsayısı; gelir dağılımı eşitsizliğinde en çok kullanılan objektif ölçütlerden biri olmuştur. Gelir eşitliği doğrusu yatay eksende kümülatif popülasyon gösterilmek üzere Şekil 1 'de görüldüğü gibi eksenlerle arasında bir kapalı alan oluşturur. Gini Katsayısı; Lorenz eğrisi ile gelir eşitliği doğrusu arasında kalan alanın bu üçgenin alanına oranıdır. 0 ile 1 arasında olan bu oran; servet nüfusta adaletli olarak paylaşıllyorsa yani gelir eşitsizliği azalıyorsa 0'a yaklaşırken serveti yalnızca bir kesim alıyorsa yani gelir eşitsizliği artıyorsa 1'e yaklaşır. Gini katsayısına ilişkin formülasyon aşağıdaki gibi verilmektedir (Filiztekin ve Çelik, 2010):

$$
G i n i=\frac{1}{2 n^{2} \bar{y}} \sum_{i=1}^{n} \sum_{j=1}^{n}\left|y_{i}-y_{j}\right|
$$

$y_{i}: i$. grubun toplam geliri

$y_{j}: j$. grubun toplam geliri

$n:$ birim sayis 1

$\bar{y}:$ tüm gelirlerin aritmetik ortalamas

Lorenz eğrisi; kümülatif gelir dağılımının grafik olarak sunumudur. Lorenz eğrisinin tanımı iki aşamada verilebilir. Belirli bir $p$ kantil değeri için Lorenz eğrisi $L(p)$; 


$$
p=F(x)=\int_{0}^{x} f(t) d t
$$

olmak üzere

$$
L(p)=\frac{1}{\mu} \int_{0}^{x} t f(t) d t=\frac{1}{\mu} \int_{0}^{p} F^{-1}(t) d t
$$

Burada paydada $\mu$ tüm nüfusun toplam geliri iken $\int_{0}^{p} F^{-1}(t) d t$ integrali nüfusun en alt $\mathrm{p}$ oranının aldığı toplam geliri göstermektedir. Dolayısıyla gelirler en küçükten büyüğe doğru sıralandığında, $L(p)$, nüfusun kümülatif $\mathrm{p}$ oranı tarafından tutulan toplam gelirin kümülatif yüzdesini gösterir. Lorenz eğirisine bağlı olarak sürekli dağılımlarda Genelleştirilmiş Lorenz $(G L)$ eğrisi, $G L(0)=0$ ve $G L(1)=1$ olmak üzere, $p \in[0,1]$ için aşağıdaki gibi verilir:

$$
G L(p)=\int_{0}^{p} F^{-1}(t) d t
$$

Diğer yandan tüm $p \in[0,1]$ değerleri için

$$
G L_{F}(p) \geq G L_{G}(p)
$$

eşitsizliği sağlanıyorsa, " $f$ dağglımı $g$ dağglımına Lorenz anlamda tercih edilir" denir.

$$
F(x)=\int_{0}^{x} f(t) d t v e \int_{0}^{x} t f(t) d t=\int_{0}^{p} F^{-1}(t) d t
$$

olduğundan, gerekli integral alma teknikleri uygulandığında SSD tanımında verdiğimiz

$$
\int_{-\infty}^{x}(G(t)-F(t)) d t \geq 0
$$

eşitsizliği ile GL eğrisinin denkliği elde edilmektedir (Thistle, 1989). SSD kriterinin yaygın olarak finans alanında kullanılan tanımı bu çalışmada, GL eğrisi ile SSD arasında yukarıda gösterilen denklikten faydalanarak, bireysel gelir dağılımları için yeniden yorumlanmıştır. Herhangi bir bölgenin bireysel gelir dağılımının bir başka bölgenin dağ 1 lımına ikinci dereceden stokastik anlamda baskın olması, o bölgenin gelir dağılımı açısından diğer bölgeden daha baskın olduğu şeklinde yorumlanabilir.

Ülkemizde kullanılan gelir dağılımı karşılaştırma analizlerinden birisi de Giriş bölümünde değindiğimiz yüzdelik paylar analizidir. Eşdeğer hanehalkı kullanılabilir gelirleri küçükten büyüğe doğru sıralanır ve bu sıralamaya göre gruplara bölünerek yüzde 5 veya yüzde 20 'lik nüfus grupları oluşturulur. Böylece her bir grubun toplam gelirden aldıkları pay elde edilerek gelir dağılımı eşitsizliği ile ilgili bilgi sağlanmış olur.

Yüzde paylar; en yüksek gelire sahip olan son yüzdelik grubun, geliri düşük olan ilk yüzdelik gruba oranı (P80/20) olarak tanımlanmaktadır (TÜİK, 2018). Yüzdelik paylar, en yüksek gelir grubu ile en düşük gelir grubu arasındaki farkın boyutunu ortaya çıkarmaktadır. Büyük olarak gerçekleşen yüzdelik paylar oranı eşitsizliğin giderek arttı̆̆ını, küçük olarak gerçekleşen oran ise eşitsizliğin azaldığını ifade etmektedir. Dolayısıyla yüzdelik paylar oranı en 
zengin ile en yoksul grupların gelirden aldıkları payların değişimini incelemeyi sağlamaktadır (Alabaş, 2015). Bu çalışmada da yalnızca hesaplama sürecinde SSD kriteri ile direk ilişkili olan eşitsizlik ölçülerine odaklanılmaktadır.

\section{TÜRKIYYE'DE BÖLGESEL GELİR EȘITSİZLİĞİ}

Dünyada ve ülkemizde bölgesel gelir eşitsizliği üzerine yapılmış oldukça fazla çalışma bulunmaktadır. Bu çalışmalar gelir eşitsizliğinin bölgesel farklar içerip içermediğinin tespiti, nedenlerinin ve sonuçlarının araştırılması gibi amaçlara ayrılabildiği gibi uygulanan analiz yöntemleri açısından da farklılıklar taşımaktadırlar. Özellikle 2000'li yıllardan sonra bölgeler arası komşuluk ilişkilerini de dikkate alan uzamsal çalışmalar da literatürde yerini bulmaktadır. Dolayısıyla bölgesel gelir eşitsizliği ülke ekonomisine dair bireyleri ilgilendiren temel konulardan biri olarak üzerine çok çalışma yapılmış ve yapılmaktadır.

Bu bölümün ilk alt başlığında, Türkiye'de bölgesel gelir eşitsizliğini konu alan çalışmalara yer verilmektedir. Daha sonra SSD kriteri ile bu çalışmalardan farklı bir bakış açısıyla, TÜİK'in Gelir ve Yaşam Koşulları Araştırması 2007-2016 yılları arası Eşdeğer hanehalkı kullanılabilir fert geliri verileri ile bölgeler arası bir analiz sunulmaktadır.

\subsection{Türkiye'de Bölgesel Gelir Eşitsizliğine Yönelik Çalışmalar}

Gerek ekonomik koşullar gerekse ülke politikaları gibi nedenlerle, diğer ülkelerde olduğu gibi Türkiye'de de gelir eşitsizliği hükümetlerin üzerinde her zaman çalışması gereken bir problem olmuştur. Türkiye'de bölgeler arası gelir eşitsizliği üzerine yapılmış çok sayıda çalışma bulunmaktadır, özellikle 2000'li yıllardan sonra bu konudaki çalışmaların sayısı oldukça artmıştır.

Yamak ve Yamak (1999) çalışmalarında, bölgesel gelir eşitsizliği ve iç göç arasındaki ilişkileri incelemişlerdir. Gelir eşitsizliğinin iç göç üzerinde etkili olduğunu ve bu etkinin net iç göç veren bir bölgenin gelirinden ziyade, bölgedeki yüksek gelir düzeyi sebebiyle yaşandığını ve her 100 kişiden 25'inin ekonomik nedenlerle göç ettiğini belirtmektedirler. Çalışmalarında ayrıca net göç veren bölgelerde kişi başına düşen gelir düzeylerinin artması durumunda, göç alan bölgelerdeki net göç hızının \%70 oranında azalacağı sonucuna varmışlardır. Diğer bir sonuç ise, bulgulara bağlı olarak kamu ve özel sektör yatırımlarının net göç veren bölgelere yapılmasına yönelik politikaların uygulanmasını önermektedirler.

1960'ların sonundan 2000 yıllarına kadar bölgeler arası gelir farklılıklarını azaltma amacıyla uygulanan politikaların sonuçlarını incelediği çalışmasında Karaca (2004), ilgili dönemde amaçlananın aksine gelir farklılıkları arasında artış olduğu bulgusuna ulaşmıştır. Karaca (2018) daha sonra genişletilmiş bir dönem için benzer bir çalışma yeni bir veri setine uygulamış ve 1960-2010 yılları arasında İBBS Düzey-2 seviyesinde bölgelerin gelir düzeyleri arasında yakınsama olmadığı bulgusuna ulaşmıştır. Bozma, Bozma ve Güney (2020) ise, TÜİK 2006-2016 Gelir ve Yaşam Koşulları anket verilerini kullanarak yaptıkları İBBS Düzey-1 bölgeler arası panel veri analizlerinde enflasyon, işsizlik ve yoksulluk arasındaki ilişkileri açıklamaya çalışmışlardır. Bozma v.d. (2020), ülke ekonomisinde geniş payları olan İstanbul, Batı Anadolu ve Ankara gibi büyük şehirlerde diğer bölgelerden göç aldığı ve bu bölgelerdeki hayat şartları nedeniyle işsizlik oranı düşerken yoksulluğun azalmadığı sonucuna ulaşmışladır.

Hepaktan ve Alkaya (2001), Türkiye'de 19 il merkezinin 1987 ve 1994 yılları arası gelir dağılımına ilişkin sonuçları yüzde paylar ve Gini katsayılarına göre incelemişler ve buna göre enflasyon, işsizlik, sosyal güvenlik hizmetleri, demokrasi ve siyaset, eğitim, nüfus artışında kontrol ve yatırımlar üzerine politikalarla gelir dağılımındaki eşitsizliğin giderilmesi üzerine 
önerilerde bulunmuşlardır. Şenesen (2003), 1975-1986 y1lları ile 1986-1999 yılları arasında tanımsal istatistikler ve varyans çözümlemeleri ile incelediği çalışmasında bölgeler arasında gelir dağılımının eşitlikten uzak olduğu sonucuna varmıştır. Ayrıca batı kıyı ve doğu iç bölgeleri arasında gelir dağglımı arasında oldukça büyük farklılıklar olduğunu vurgulamıştır.

1965-2001 yılları arası gibi geniş bir dönemi kapsayan araştırmasında Öztürk (2005), 1980 yılları sonuna kadar gelir eşitsizliğinin artış eğiliminde olduğu, 1990'lı yıllarda ise azalarak 1960’lı yıllar seviyesine indiğini saptamıştır. Ancak bu azalışın genel olarak bölgesel dengesizliklerin azaldığı anlamına gelmeyebileceğine ve bölgelerarası eşitsizlikte 1986 yılından sonra görülen azalmaları etkileyen farklı araştırmalara konu olabilecek pek çok farklı etken olduğunu belirtmektedir. Genel olarak bölgelerarası gelir eşitsizliğindeki farklılıkların, göç alan bölgelerdeki nüfus artışı nedeniyle kişi başına düşen gelirlerdeki azalma ve tersine göç veren bölgelerde ise kişi sayısındaki azalma sebebiyle kişi başına gelir hesabında oluşan artıştan kaynaklanabileceği belirtilmektedir. Sonuç olarak bölgeler arası gelir eşitsizliğinin farklı sosyoekonomik değişkenler açısından incelendiğinde gelir düzeylerine ilişkin elde edilen indekslere göre daha farklı sonuçlar elde edilebileceğine değinmektedir.

Kuştepeli ve Halaç (2004), çalışmalarında hanehalkı bütçe anketlerinden yararlanarak bölgesel gelir dağılımlarını yıllara göre incelemişlerdir. Buna göre; kişisel gelir dağılımlarında az da olsa bir iyileşme eğilimi görüldüğü bulgusunu elde etmişlerdir. Türkiye'de genel gelir dağılımında iyileştirmenin sürdürülebilir ve sağlıklı olması için kırsal kesimde iş imkanlarının yaratılması, göçün önüne geçilmesi, eğitim kalitesinde farklılıkların azaltılması ve tarıma dayalı sanayinin geliştirilmesi konularına dikkati çekmişlerdir. Ayrıca, Türkiye'de bölgeler arası gelir düzeylerinin zamanla nasıl değiştiğini, yakınsama hipotezi ile test eden çok sayıda çalışma bulunmaktadır.

Ersungur ve Polat (2006), İBBS Düzey-1'e göre kişi başına gelir düzeylerinin bölgelere göre birbirlerine yakınsaması üzerine bir analiz yapmışlardır. Bu analizde kriz dönemlerinde tüm bölgelerde kişi başına gelir düzeylerinde büyük düşüşler meydana geldiğini dolayısıyla bunun bölgelerin kişi başına gelir seviyelerinin yakınlaşmasına katkıda bulunduğuna değinmişlerdir. Çünkü krizlerin yaşanmadığı dönemlerde, bölgeler arası kişi başına gelir seviyeleri arasındaki farkın hızlı bir şekilde arttığını ve gelir seviyesi yüksek olan bölgelerde diğerlerine göre bu artışın hızlandığını gözlemlemişlerdir. Krizlerin yaşanmadığı bu dönemlerde bölgeler arası gelir düzeylerinde farkın hızlı bir şekilde artmasının bölge ekonomileri arasındaki yapısal farklılıkları işaret ettiğine değinmişlerdir.

Nal (2019), 2004-2017 y1lları arasını kapsayan analizinde 2004 sonrasında bölgesel ve il düzeyinde gelir farklılıklarının azaldığını ortaya çıkarmış, özellikle 2007'den sonra şehirleşme düzeyindeki artışın ve modernleşmenin de bunda etkisi olduğunu vurgulamıştır. İşgücü başına gelirin kişi başına düşen gelire göre daha hızlı yakınsama göstermesi bulgusuna göre; modernleşmenin tüm bölgelere yayılabilmesiyle bölgeler arası gelir farklılıklarının kişi başına gelir bazında hızlı bir şekilde azalabileceğine değinmektedir.

Tokatlığlu ve Atan (2007), Türkiye'de ekonomik gelişme ile gelir eşitsizliği arasında pozitif yönlü bir ilişkinin olduğunu belirtmektedirler. Bölgesel farklılıkları dikkate almadan gelir dağılımı ve yoksulluk üzerinde durulduğunda Gini katsayısının azaldığı ancak yaratılan gelirin bölgesel dağılımı söz konusu olduğunda gelir eşitsizliğinin giderilemediğine değinmektedirler.

Filiztekin ve Çelik (2010), Batı Karadeniz ile Kuzey Doğu, Orta Doğu ve Güney Doğu Anadolu bölgelerinde 1994-2003 yılları arası gelir eşitsizliğinin ciddi bir biçimde yükselmiş olmasına değinmektedirler. Bu bölgelerdeki toplumsal refahın artması için daha detaylı çalışmalarla belirlenecek yeni politikalar izlenmesi gerektiğini vurgulamaktadırlar. Yazarlar, eğitim ve iş tecrübesinin ücretlere farklılık olarak yansıması nedeniyle, geliri yüksek olan bölgeler arasında gelir eşitsizliği farklılıkları oluştuğunu tahmin etmektedirler. Diğer yandan 
tarımdaki gelir azalırken yine tarımdaki istihdamın eşit ölçüde azalmaması, geliri düşen kesimlerde daha fazla ortalama hane büyüklüğü görülmesi de gelir eşitsizliğinin nedenlerinden görülebilir. Filiztekin (2020)'de Türkiye'deki gelir dağılımının 2003-2015 yılları arası için bir incelemesini sunmakta ve hane halkı eğitim düzeyi ile gelir eşitsizliği arasında yakın bir ilişki olduğuna işaret etmektedir. Ayrıca 2007'den sonra yoksul kesimin orta sınıflara yaklaştığına, nüfusun devlet transferlerine olan bağımlılı̆̆ına ve transferlerin sürdürülebilir olmaması durumunda gelir eşitsizliğinin daha da artabileceğine işaret etmektedir.

Coşkun (2012) ise, 1994-2001 yılları arası Hanehalkı Gelir ve Tüketim Harcamaları Anketi ham verilerinden Türkiye'de yoksulluğun profilini ele almıştır. Yoksulluğun genel tanımına göre, belirli gelir düzeyleri altında kalanların bölgeler arası karşılaş̧ırmalarını dikkate aldığı çalışmada yoksullukla mücadele için istihdam yaratan ve gelir dağılımını düzenleyen ekonomik politikalar belirlenmesini önermektedir. Alabaş (2015) ise, Türkiye'de bölgeler arası gelir dağılımı eşitsizlik düzeyleri ile işsizlik, yoksulluk oranı ve net göç hızı arasındaki ilişkileri incelemektedir. Çalışmada, İBBS Düzey-1 seviyesinde karşıllaştırmalara göre bölgeler arasında farklı ekonomik koşullar nedeniyle farklı değerlendirmeler elde edilmektedir. Aynı dönem için benzer bir çalışma Acar (2015) tarafından ele alınmıştır. Çalışmaların sonuç kısımlarında gelir dağılımındaki eşitsizliği önlemek amacıyla devletin izleyebileceği mali politikalar maddeler halinde sıralanmaktadır.

Topuz ve Sekmen (2020) bulgularına göre, Türkiye'de bölgelerarası gelir dağılımı önemli ölçüde farklılaşmaktadır. İstanbul ve Batı Marmara bölgeleri gelirden en yüksek payı alırken aynı zamanda en adaletsiz gelir dağılımına sahip bölgelerdir. Çalışmada İstanbul'un diğer bölgelere göre en gelişmiş iktisadi bölge olması, iktisadi gelişme ya da büyümenin gelir eşitsizliğini azaltmakta başarılı olamadığı sonucuna varılmaktadır. En adil gelir dağılımının olduğu bölge olarak Orta Doğu Anadolu, yüksek gelir grubundakilerin diğer bölgelere göre daha düşük gelir düzeyine sahip olmasından kaynaklandığı bir örnek olarak gösterilmektedir. İktisadi açıdan en az gelişmiş bölgeler olan Kuzey ve Orta Doğu Anadolu, yoksulluğun yüksek iken aynı zamanda gelir eşitsizliğinin az olduğu bölgelere örnek olarak verilmektedir (Topuz ve Sekmen, 2020).

Şık ve Öztürk (2019), bölgesel gelir eşitsizliğine sebep olan faktörler üzerine 2006-2018 yılları için bölgeler arası bir karşılaştırma yapmışlar ve tarım, sanayi ve hizmet sektörlerinin eşit dağıldığ 1 bölgelere nazaran tek bir sektörün yoğun olduğu bölgelerde gelir eşitsizliğini daha yüksek olarak tespit etmiş̧lerdir. İşsizlik, istihdam yoksulluk ve göçün yanı sıra coğrafi yapı ve nüfus yoğunluğunun da önemli ve doğal birer faktör olduğunu belirtmekte, bu konulara yönelik politikalar önermektedirler. Bozkurt, Altıner ve Topçu (2020) da Türkiye'de 1970 ve 2015 yılları arasını kapsayan çalışmalarında doğrusal yabancı yatırımların da gelir eşitsizliğini arttırdığg sonucuna varmışlardır.

\subsection{Analiz}

$\mathrm{Bu}$ çalışmada, Türkiye İBBS Düzey-1'e göre kişisel gelirlerin SSD kriteri ile karşılaş̧ırması yapılmaktadır. Analizde veri seti TÜİK'in Gelir ve Yaşam Koşulları Araştırması, 2007-2016 yılları arası Eşdeğer hanehalkı kullanılabilir fert gelirinden oluşmaktadır².

Bölgeler arası yaşam koşullarının farklılığı nedeniyle fertlerin satın alma güçleri de farklı1ık gösterebileceğinden, gelirler Tüketici Harcamaları Fiyat Endeksi (THFE)'ne göre yeniden düzenlenmiş̧tir. Buna göre, yıllara göre gelir dağılımlarının tanımsal istatistikleri .

\footnotetext{
${ }^{2}$ Eşdeğer hanehalkı kullanılabilir fert gelirleri (kesit verisi), "ferdin referans y1lı içinde elde ettiği gelirlerin toplam değeri” dir. TÜIK' in bu araştırmasında, gelir bilgilerinin referans dönemi bir önceki takvim yılı olarak belirtilmiştir.
} 
Tablo 1'de verilmektedir.

\section{Tablo 1: Tanımsal İstatistikler}

\begin{tabular}{lcccccc} 
Yıllar & En küçük & 1. Kartil & Medyan & Ortalama & 3. Kartil & En büyük \\
\hline $\mathbf{2 0 0 7}$ & -56047 & 3131 & 5992 & 8018 & 9868 & 278460 \\
$\mathbf{2 0 0 8}$ & -117704 & 3806 & 6760 & 9183 & 11208 & 333672 \\
$\mathbf{2 0 0 9}$ & -52353 & 3594 & 7089 & 9515 & 11744 & 369172 \\
$\mathbf{2 0 1 0}$ & -51173 & 3899 & 7750 & 10308 & 12861 & 296985 \\
$\mathbf{2 0 1 1}$ & -19204 & 4502 & 8594 & 11554 & 14175 & 341542 \\
$\mathbf{2 0 1 2}$ & -108282 & 5475 & 9484 & 12804 & 15585 & 306629 \\
$\mathbf{2 0 1 3}$ & -19081 & 6026 & 10653 & 14264 & 17541 & 429481 \\
$\mathbf{2 0 1 4}$ & -21674 & 6821 & 11822 & 15706 & 19211 & 531349 \\
$\mathbf{2 0 1 5}$ & -18079 & 8152 & 13140 & 17825 & 21891 & 297608 \\
$\mathbf{2 0 1 6}$ & -30899 & 9711 & 15245 & 20550 & 24952 & 454177 \\
\hline
\end{tabular}

TÜIKK'in Gelir ve Yaşam Koşulları Araştırması sonuçlarında raporlanan bölgelere göre Gini katsayıları ise Tablo 2'de verilmektedir³. Gini katsayısının yüksek bir değer olması bir bölgedeki gelir eşitsizliğinin yüksek olduğuna işaret etmektedir. 2007 ve 2016 yılları arasında, Gini katsayısının özellikle Akdeniz (TR6), Doğu Anadolu bölgeleri (TRA, TRB ve TRC) ve son yıllarda Batı Anadolu (TR5) ve İstanbul (TR1)'da en yüksek değerlerine ulaştığı görülmektedir. En düşük değerini genellikle Doğu ve Batı Karadeniz ve Doğu ve Batı Marmara (TR9 ve TR8, TR4 ve TR2) bölgelerinde almıştır.

Tablo 2: Yıllara Göre Gini Katsayıları

\begin{tabular}{ccccccccccc}
\hline & $\mathbf{2 0 0 7}$ & $\mathbf{2 0 0 8}$ & $\mathbf{2 0 0 9}$ & $\mathbf{2 0 1 0}$ & $\mathbf{2 0 1 1}$ & $\mathbf{2 0 1 2}$ & $\mathbf{2 0 1 3}$ & $\mathbf{2 0 1 4}$ & $\mathbf{2 0 1 5}$ & $\mathbf{2 0 1 6}$ \\
\hline TR1 & 0,35 & 0,36 & 0,36 & 0,37 & 0,37 & 0,38 & 0,39 & 0,37 & 0,4 & 0,41 \\
TR2 & 0,32 & 0,33 & 0,36 & 0,36 & 0,37 & 0,36 & 0,34 & 0,33 & 0,35 & 0,36 \\
TR3 & 0,38 & 0,39 & 0,38 & 0,39 & 0,4 & 0,38 & 0,37 & 0,36 & 0,36 & 0,36 \\
TR4 & 0,39 & 0,34 & 0,37 & 0,34 & 0,33 & 0,34 & 0,32 & 0,34 & 0,34 & 0,33 \\
TR5 & 0,38 & 0,4 & 0,41 & 0,37 & 0,37 & 0,37 & 0,4 & 0,4 & 0,39 & 0,4 \\
TR6 & 0,42 & 0,39 & 0,4 & 0,4 & 0,4 & 0,41 & 0,4 & 0,4 & 0,4 & 0,4 \\
TR7 & 0,33 & 0,34 & 0,4 & 0,36 & 0,37 & 0,36 & 0,34 & 0,36 & 0,34 & 0,36 \\
TR8 & 0,36 & 0,37 & 0,38 & 0,35 & 0,34 & 0,34 & 0,33 & 0,34 & 0,34 & 0,34 \\
TR9 & 0,35 & 0,37 & 0,36 & 0,33 & 0,33 & 0,31 & 0,32 & 0,31 & 0,33 & 0,36 \\
TRA & 0,41 & 0,44 & 0,41 & 0,4 & 0,39 & 0,39 & 0,4 & 0,4 & 0,38 & 0,35 \\
TRB & 0,4 & 0,41 & 0,42 & 0,42 & 0,43 & 0,39 & 0,37 & 0,39 & 0,38 & 0,39 \\
TRC & 0,37 & 0,4 & 0,41 & 0,4 & 0,4 & 0,38 & 0,38 & 0,38 & 0,38 & 0,37 \\
\hline
\end{tabular}

Kaynak: TÜİK, 2018, Gelir ve Yaşam Koşulları Araştırması, kesit verileri.

\footnotetext{
3 İBBS'ye göre 12 bölge kodlarıyla birlikte sırasıyla, İstanbul (TR1), Batı Marmara (TR2), Ege (TR3), Doğu Marmara (TR4), Batı Anadolu (TR5), Akdeniz (TR6), Orta Anadolu (TR7), Batı Karadeniz (TR8), Doğu Karadeniz (TR9), Kuzey Doğu Anadolu (TRA), Orta Doğu Anadolu (TRB) ve Güney Doğu Anadolu (TRC) olarak verilmektedir.
} 
TÜIK'in Gelir ve Yaşam Koşulları Araştırması sonuçlarında raporlanan bölgelerin Eşdeğer hane halkı kullanılabilir fert gelirine göre sıralı yüzdelik gruplara ait değerlerden hesaplanan yüzdelik paylar (P80/P20) Tablo 3'te yıllara göre verilmektedir. Ancak 2014, 2015 ve 2016 yılları için yüzdelik paylar bölgesel yalnızca Türkiye geneli için raporlandığından yalnızca 2007-2013 yılları arası için oranlar bölgesel olarak elde edilebilmiştir. Yüzdelik paylar arttıkça bir bölgedeki gelir eşitsizliği de artmaktadır. Genellikle Doğu Anadolu bölgelerinde (TRA, TRB ve TRC), Ege (TR3) ve Akdeniz (TR6)'da oranın en yüksek değerlerine ulaştığı, Doğu Karadeniz (TR9)'da ise en düşük değerlerini aldığı görülmektedir.

Görüldüğü gibi bölgeler arası yapısal farklılıklar, bölgesel gelir eşitsizliklerini ifade eden katsayılarda da yıldan yıla dalgalanmalarda farklılık yaratmaktadır.

Tablo 3: Yıllara Göre Bölgesel Yüzde Payları (P80/P20)

\begin{tabular}{lccccccc}
\hline & $\mathbf{2 0 0 7}$ & $\mathbf{2 0 0 8}$ & $\mathbf{2 0 0 9}$ & $\mathbf{2 0 1 0}$ & $\mathbf{2 0 1 1}$ & $\mathbf{2 0 1 2}$ & $\mathbf{2 0 1 3}$ \\
\hline TR1 & 5,24 & 6,03 & 5,89 & 6,32 & 6,26 & 6,44 & 6,65 \\
TR2 & 5,26 & 5,69 & 6,42 & 6,53 & 6,35 & 6,17 & 5,44 \\
TR3 & 6,69 & 7,17 & 6,76 & 6,82 & 7,14 & 6,69 & 6,29 \\
TR4 & 6,7 & 5,28 & 6,14 & 5,55 & 5,06 & 5,59 & 5,00 \\
TR5 & 6,27 & 7,31 & 7,68 & 6,64 & 6,71 & 6,53 & 7,07 \\
TR6 & 8,08 & 6,55 & 7,18 & 7,12 & 7,28 & 7,45 & 7,10 \\
TR7 & 5,11 & 5,6 & 6,75 & 6,17 & 6,27 & 6,28 & 5,56 \\
TR8 & 6,07 & 6,05 & 6,97 & 6,18 & 5,66 & 5,62 & 5,39 \\
TR9 & 5,67 & 6,38 & 6,21 & 5,28 & 5,1 & 4,72 & 4,73 \\
TRA & 7,88 & 8,84 & 7,8 & 7,56 & 6,97 & 7,22 & 7,26 \\
TRB & 7,17 & 7,06 & 7,46 & 7,69 & 8,39 & 7,05 & 6,41 \\
TRC & 6,3 & 7,01 & 7,95 & 7,24 & 7,47 & 6,76 & 6,66 \\
\hline
\end{tabular}

Kaynak: TÜİK, 2018, Gelir ve Yaşam Koşulları Araştırması, kesit verileri.

Bölgelere ait gelir dağılımlarının SSD kriteri ile karşılaştırılması için her bölgenin gelir dağılımına ait veriler öncelikle düşükten yükseğe doğru sıralanmıştır. Sıralanmış verilerin Bölüm 2'de verilen (3) formülüne göre karşılaştırılabilmesi için her bir gelir dağılımındaki veri uzunluğu eşit olmalıdır. Analizde kullanılan verilerin uzunlukları eşit olmadığından, ham hali ile gelir dağılımlarının karşılaştırması mümkün olamamaktadır. Bu nedenle sıralı gelir dağılımların bölünebileceği şekilde 1000 olarak bir ortak parça sayısı seçilmiş ve gelir dağılımları arasında SSD kriterine göre karşılaştırmalar (3) formülü kullanılarak yapılabilmiştir.

Tüm veri düzenlemeleri ve formüle dayalı hesaplamalar istatistik tabanlı $\mathrm{R}$ paket programında yapılmıştır ${ }^{4}$. Buna göre 1000 parçaya (düzeye) ayrılan her iki gelir dağılım için, herhangi bir ferdin elde ettiği gelir düzeyi ve daha düşük gelire sahip olanların ortalamaları (3) formülündeki gibi karşılaştırılmıştır. Yıllara göre karşılaştırma sonuçlarının sunulduğu

\footnotetext{
${ }^{4}$ R Core Team (2020). R: İstatistiksel hesaplamalar için bir dil ve ortam. R Foundation for Statistical Computing, Vienna, Austria. Çevrim-içi: https://www.R-project.org/.
} 
tablolarda, satır ve sütun kesişimlerinde yer alan 1000 değerleri her bir düzeyde satır bölgenin gelir dağılımı ortalamasının sütun bölgenin gelir dağılımdan eşit veya daha yüksek olduğu yani SSD kriterine göre baskın olduğu bilgisini içermektedir. Diğer değerler için ise iki bölgeden herhangi birinin diğerine SSD kriterine göre baskın olduğu hakkında bir şey söylenememektedir.

\subsection{Bulgular}

Tablo 4'te 2007 yılı için bölgeler arası karşılaştırma sonuçlarına bakıldığında SSD kriteri ile en fazla sayıda baskınlık alan bölgenin İstanbul (TR1) olduğu görülmektedir. İstanbul (TR1)'a ait gelir dağılımı 7 bölgeye ikinci dereceden stokastik baskındır. Gelir dağılımının baskınlığı; her bir gelir düzeyi için herhangi bir ferdin elde ettiği gelir ve daha düşük gelir düzeylerine sahip olanların ortalaması, İstanbul (TR1)'un karşılaştırıldığı diğer bölgedeki aynı gelir düzeyine denk gelen fertlere göre eşit veya daha fazladır, şeklinde yorumlanabilir. İstanbul (TR1), Doğu Marmara (TR4), Batı Anadolu (TR5) ve Orta Anadolu (TR7)'nun gelir dağılımları Akdeniz (TR6)'e baskındır. Bu sonuç Akdeniz (TR6)'in 2007 yılında Gini katsayısı en yüksek bölge olmasıyla da tutarlıdır ve bu dört bölge ile Akdeniz (TR6) arasında gelir eşitsizliğinin olduğu açıkça söylenebilir. Ancak İstanbul (TR1) ile aynı Gini katsayısına sahip olmasına rağmen Doğu Karadeniz (TR9)'in Akdeniz (TR6)'e baskın olduğu söylenememektedir.

2007 yılında Gini katsayısı için geçerli olan yorumlar bölgelere ait yüzde paylar açısından da geçerlidir. SSD kriterine göre bölge içindeki dağılıma ait daha özet bilgiler verdiğinden Gini katsayısı ve yüzde paylar ile bu ayrım incelenememektedir. Ayrıca Doğu Karadeniz (TR9)'in hiçbir bölgeye baskınlığı bulunmazken, hiçbir bölgenin de bu bölge üzerinde gelir dağılımı açısından baskınlığı bulunmamaktadır.

Tablo 4: 2007 Yılına Ait Karşılaştırmalar

\begin{tabular}{lcccccccccccc}
\hline $\mathbf{2 0 0 7}$ & TR1 & TR2 & TR3 & TR4 & TR5 & TR6 & TR7 & TR8 & TR9 & TRA & TRB & TRC \\
\hline TR1 & 0 & $\mathbf{1 0 0 0}$ & $\mathbf{1 0 0 0}$ & 635 & 977 & $\mathbf{1 0 0 0}$ & 859 & $\mathbf{1 0 0 0}$ & 655 & $\mathbf{1 0 0 0}$ & $\mathbf{1 0 0 0}$ & $\mathbf{1 0 0 0}$ \\
TR2 & 0 & 0 & 984 & 0 & 0 & 952 & 0 & 933 & 310 & 858 & 984 & 903 \\
TR3 & 0 & 0 & 0 & 0 & 0 & 304 & 0 & 134 & 41 & 23 & 63 & 816 \\
TR4 & 364 & 988 & 988 & 0 & 943 & $\mathbf{1 0 0 0}$ & 967 & 988 & 655 & $\mathbf{1 0 0 0}$ & 988 & 985 \\
TR5 & 22 & 989 & 989 & 46 & 0 & $\mathbf{1 0 0 0}$ & 747 & 989 & 503 & $\mathbf{1 0 0 0}$ & 989 & 989 \\
TR6 & 0 & 48 & 696 & 0 & 0 & 0 & 0 & 46 & 69 & 27 & 75 & 764 \\
TR7 & 140 & 992 & 992 & 25 & 245 & $\mathbf{1 0 0 0}$ & 0 & 992 & 455 & 940 & 992 & 992 \\
TR8 & 0 & 51 & 849 & 0 & 0 & 954 & 0 & 0 & 68 & 27 & 73 & 792 \\
TR9 & 344 & 674 & 939 & 333 & 486 & 931 & 537 & 915 & 0 & 825 & 965 & 877 \\
TRA & 0 & 142 & 977 & 0 & 0 & 973 & 60 & 973 & 175 & 0 & 977 & 951 \\
TRB & 0 & 0 & 917 & 0 & 0 & 925 & 0 & 910 & 6 & 23 & 0 & 864 \\
TRC & 0 & 86 & 173 & 4 & 0 & 236 & 0 & 197 & 112 & 49 & 125 & 0 \\
\hline
\end{tabular}

2007 yılında ayrıca Batı Marmara (TR2) en düşük Gini katsayısına sahip bölge olmasına rağmen diğer bölgelerden herhangi birine baskınlık sağlayamamıştır. Dahası Tablo 4'ten de görülebildiği gibi İstanbul (TR1)'un gelir dağılımı, 0,35 olan Gini katsayısına rağmen, Batı Marmara (TR2)'nın gelir dağılımına baskındır. İstanbul (TR1)'daki sıralı gelirler dikkate alındığında, herhangi bir ferdin elde ettiği gelir ve daha düşük gelir düzeylerine sahip olanların ortalamas1 Batı Marmara (TR2)'da aynı gelir düzeyine denk gelen fertlere eşit veya daha azdır. 
Bu sonuç İstanbul ve Batı Marmara gelir dağılımları arasındaki gelir eşitsizliğini ortaya koyması açısından Tahsin (2019) ve Topuz ve Sekmen (2020) ile tutarlıdır.

Bölgelerin yüzde paylarına da bakıldığında 2007 yılı için Gini katsayısı açısından yapılan değerlendirmeler paralel sonuçlar vermektedir. Gini katsayısı veya yüzde paylara göre gelir eşitsizliği en fazla Akdeniz (TR6) ve Kuzey Doğu Anadolu (TRA) bölgeleri ile Batı Marmara (TR2) ve Orta Anadolu arasındadır. SSD kriterine göre ise gelir eşitsizliği en fazla Akdeniz (TR6) ve Kuzey Doğu Anadolu (TRA) bölgeleri ile İstanbul (TR1), Doğu Marmara (TR4), Batı ve Orta Anadolu (TR5 ve TR7) bölgeleri arasındadır. Bu karşılaştırma, SSD kriteri ile, Gini katsayısı veya yüzde paylara göre elde edilenden daha fazla ve farklı olarak da bilgi sağlanabildiği görülmektedir.

EK'te 2008 ve 2016 yılları ve arası için karşılaştırma tabloları verilmektedir. 2007 yılı için yapılan yorumların paralelinde, 2008 ile 2016 yılları ve arası için değerlendirmeler ise aşağıda sıralanmaktadır;

Tablo 6'dan 2008 yılında en yüksek Gini katsayısı ve yüzde paylar Kuzey Doğu Anadolu (TRA)'da gözlenmektedir. Ancak Kuzey Doğu Anadolu (TRA)'ya SSD kriterine göre baskın olan tek diğer bölge Doğu Karadeniz (TR9) olabilmiştir. Diğer yandan, Gini katsayısı ve yüzde payları oldukça farklı değerler olan Doğu Marmara (TR4) ve Batı Anadolu (TR5) gelir dağılımları aynı bölgelere stokastik baskınlık sağlamaktadırlar. Dolayısıyla eşitsizlik açısından, Gini katsayı ve yüzde paylar Kuzey Doğu Anadolu (TRA)'yı gösterirken, SSD kriteri öncelikle Ege (TR3), Akdeniz (TR6) ve Güney Doğu Anadolu (TRC) bölgelerini işaret etmektedir.

2009 yılında Gini ve yüzde paylar açısından önceki yıllara göre tüm bölgelerin birbirine yakın ve yüksek değerler aldığı Tablo 7'den görülmektedir. Ancak SSD kriteri neredeyse diğer tüm bölgelerin gelir dağılımının baskın olduğu Güney Doğu Anadolu (TRC)'yu ön plana çıkarmaktadır. En düşük Gini katsayısına sahip bölgelerden biri olan Batı Marmara (TR2), hem yüzdelik paylar hem de SSD kriteri açısından farklılık göstermektedir.

Tablo 8'e göre 2010 yılında ise, Doğu Karadeniz (TR9) en düşük Gini katsayısına sahipken yalnızca bir bölgeye baskındır. Batı Karadeniz (TR8) gelir dağılımı hiçbir bölgeden daha baskın değilken, hiçbir bölge de Batı Karadeniz (TR8)'in gelir dağılımından baskın olamamıştır. 2009 yılında olduğu gibi SSD kriteri ile en çok baskın olunan bölge Güney Doğu Anadolu (TRC)'dur. Genel olarak 2009'dan 2010'a gelindiğinde katsayllarda düşüşler gözlenebilirken, bölgelerin birbirlerine aldıkları SSD kriterine göre baskınlık sayıları da toplamda azalmıştır. Bu durum gelir eşitsizliğinin bir önceki yıla göre azaldığını işaret eden Gini katsayısı ve yüzde paylar ile SSD kriteri arasında tutarlı bir sonuçtur.

2011 yılında da 2010 yılına benzer sonuçlar elde edildiği Tablo 9'dan gözlenmektedir. En yüksek Gini katsayısı ve yüzde paylara sahip Orta Doğu Anadolu (TRB) hiçbir bölgeye göre baskın değilken hiçbir bölgenin gelir dağılımı da Orta Doğu Anadolu (TRB)'den baskın olamamıştır. 2011'de gelir eşitsizliğinin en yüksek boyutta olduğu bölgeler en çok baskınlık alınan Ege (TR3) ve Güney Doğu Anadolu (TRC) olarak gösterilebilir.

Tablo 10'a göre 2012 yılında, Gini katsayısı ve yüzde paylara göre en düşük değerler Doğu Karadeniz (TR9) da gözlenmiş ve SSD kriterine göre de bu bölgenin gelir dağılımı diğer bölgelere baskın olmuştur. En yüksek katsayılar ise Akdeniz (TR6)'da gözlenmiş ve bölgelerin çoğu bu bölge üzerinde baskın olmuştur. Genel olarak baskınlık alabilen bölge sayısı ve baskınlık sayıları artarken Batı Karadeniz (TR8) ve Güney Doğu Anadolu (TRC) hiç baskınlık alamamışlardır. 2013 ve 2014 yıllarında da (Tablo 11 ve Tablo 12) Doğu Karadeniz (TR9)'in gelir dağılımı 2012 yılında olduğu gibi tüm bölgelere baskındır. Şık ve Öztürk (2019), bölgesel gelir eşitsizliğinin nedenlerini ele aldıkları çalışmalarında, Doğu Karadeniz (TR9)'da yıllara göre azalan işsizlik oranlarına ve artan istihdama dikkati çekmektedirler. Dolayısıyla Doğu Karadeniz (TR9)'de gözlenen tüm bölgelere göre SSD kriteri ile baskın olma durumu, Şık ve Öztürk (2019) 
ile örtüşmektedir. 2013 yılında, Doğu Marmara (TR4) ve Doğu Karadeniz (TR9) aynı ve en düşük Gini katsayısı değerine rağmen, Doğu Marmara (TR4) yalnızca bir tek bölgeye göre baskınlık alabilmiştir.

Tablo 11'e göre 2015 yılında, İstanbul (TR1) ve Akdeniz (TR6) aynı Gini katsayısına sahip ancak İstanbul (TR1), Akdeniz (TR6) bölgesine baskındır ve Akdeniz (TR6) hiçbir bölgeye baskınlık alamazken İstanbul (TR1) 6 farklı bölgeye göre baskınlık almıştır. 2016 yılına ait karşılaştırma sonuçlarını içeren Tablo 12'ye göre; Doğu Karadeniz (TR9) 2009-2015 yılları arasında diğer bölgelere göre Gini katsayısının en düşük değerlere indiği bölgelerden biri olmasına rağmen, 2016 yılında yalnızca bir bölgeye Doğu Marmara (TR7) SSD kriterine göre baskındır.

Tüm yıllar için ilgi çekici sonuç ise, genellikle (Doğu Karadeniz için 2012, 2013 ve 2014 yılları dışında) herhangi bir yılda en düşük Gini katsayısına sahip bölgenin gelir dağılımının, en yüksek Gini katsayısına sahip bölgenin gelir dağılımına SSD kriterine göre baskın olamamasıdır. SSD kriterine bölgeler arası karşılaştırmalarda daha ayrıntılı bilgi sağlamaktadır.

Yıllara göre ya da bölgelere göre toplam alınan baskınlık sayıları farklılıklar göstermektedir. Bu nedenle, Tablo 5'te tüm tabloların özeti niteliğinde bölgelerin y1llara bağlı olarak aldıkları baskınlık sayılarını verilmektedir. Yıllara göre toplam alınan baskınlık sayılarında özellikle 2007 ve 2011'de yaşanan düşüşleri, bu yılları izleyen yılda yaşanan ani artışlar takip etmiştir. Toplam baskınlık sayıları bölgelere göre incelendiğinde ise en fazla İstanbul (TR1) ve Doğu Karadeniz (TR9) bölgelerinde gözlenmektedir.

Tablo 5: Yıllara Göre Bölgelerin SSD Sayıları

\begin{tabular}{cccccccccccc} 
& $\mathbf{2 0 0 7}$ & $\mathbf{2 0 0 8}$ & $\mathbf{2 0 0 9}$ & $\mathbf{2 0 1 0}$ & $\mathbf{2 0 1 1}$ & $\mathbf{2 0 1 2}$ & $\mathbf{2 0 1 3}$ & $\mathbf{2 0 1 4}$ & $\mathbf{2 0 1 5}$ & $\mathbf{2 0 1 6}$ & Toplam \\
\hline TR1 & 7 & 5 & 3 & 3 & 2 & 4 & 7 & 6 & 6 & 5 & $\mathbf{4 8}$ \\
TR2 & 0 & 1 & 3 & 3 & 0 & 5 & 8 & 4 & 0 & 1 & $\mathbf{2 5}$ \\
TR3 & 0 & 0 & 1 & 0 & 0 & 0 & 0 & 0 & 0 & 0 & $\mathbf{1}$ \\
TR4 & 2 & 5 & 5 & 3 & 2 & 2 & 1 & 0 & 3 & 1 & $\mathbf{2 4}$ \\
TR5 & 2 & 5 & 5 & 3 & 2 & 3 & 4 & 3 & 5 & 5 & $\mathbf{3 7}$ \\
TR6 & 0 & 0 & 1 & 1 & 0 & 0 & 0 & 0 & 0 & 0 & $\mathbf{2}$ \\
TR7 & 1 & 8 & 5 & 3 & 2 & 7 & 2 & 0 & 3 & 0 & $\mathbf{3 1}$ \\
TR8 & 0 & 0 & 0 & 0 & 0 & 0 & 2 & 3 & 0 & 0 & $\mathbf{5}$ \\
TR9 & 0 & 6 & 3 & 1 & 0 & 11 & 11 & 11 & 1 & 1 & $\mathbf{4 5}$ \\
TRA & 0 & 0 & 1 & 1 & 2 & 3 & 0 & 4 & 5 & 4 & $\mathbf{2 0}$ \\
TRB & 0 & 3 & 1 & 0 & 0 & 0 & 0 & 1 & 0 & 1 & $\mathbf{6}$ \\
TRC & 0 & 0 & 0 & 0 & 0 & 0 & 0 & 0 & 0 & 0 & $\mathbf{0}$ \\
\hline Toplam & $\mathbf{1 2}$ & $\mathbf{3 3}$ & $\mathbf{2 8}$ & $\mathbf{1 8}$ & $\mathbf{1 0}$ & $\mathbf{3 5}$ & $\mathbf{3 5}$ & $\mathbf{3 2}$ & $\mathbf{2 3}$ & $\mathbf{1 8}$ & \\
\hline
\end{tabular}

2007 yılından 2016 yılına doğru gelindiğinde Ege (TR3), Akdeniz (TR6) ve Güney Doğu Anadolu (TRC) bölgeleri genel olarak en yüksek Gini katsayısı ve yüzdelik paylar değerleri ile en az sayıda baskınlık alan bölgeler olmuştur. Güney Doğu Anadolu (TRC) bölgesi gelir dağılımı herhangi bir yılda hiçbir bölgeden daha baskın olmamıştır. Ege (TR3) ise 2009 yılında yalnızca bir kez Güney Doğu Anadolu (TRC) bölgesine, Akdeniz (TR6) ise 2009 ve 2010 yılında toplamda yalnızca iki kez ikinci dereceden stokastik baskınlık sağlayabilmektedir. 
Gelir eşitsizliği açısından en düşük baskınlık sayılarına sahip olarak elde edilen bu bölgelere ait sonuçlar Tahsin (2019) ile de tutarlıdır.

Genellikle bölgelerin baskınlık sayılarında herhangi bir artı̧̧ yokken Doğu Karadeniz (TR9) bölgesi 2012, 2013 ve 2014 yıllarında tüm bölgelere göre baskınlığını sürdürmüştür. Kuzey Doğu Anadolu (TRA)'da genel olarak Gini katsayıları ve yüzde paylar yıllar geçtikçe azalmış ve 2016’ya gelindiğinde diğer bölgelere göre baskınlık sayıları da artmıştır. Benzer şekilde Doğu Karadeniz en düşük Gini katsayılarının gerçekleştiği yıllarda en yüksek baskınlık sayılarına ulaşmıştır. Gini katsayısı en düşük değerde olmamasına rağmen, İstanbul (TR1), Batı Anadolu (TR5) ve Doğu Karadeniz (TR9) en yüksek baskınlıkları alan bölgeler olmuşlardır.

Genel olarak toplamda en fazla baskınlık alan İstanbul (TR1)'un gelir dağılımına baskınlığı olan tek bölge 2012, 2013 ve 2014 yıllarında olmak üzere Doğu Karadeniz (TR9) olabilmiştir.

Bölgelerden hiçbirinin gelir dağılımı ise Doğu Karadeniz (TR9)'in gelir dağılımına SSD kriterine göre baskınlık sağlayamamıştır. Bir bölgenin aldığı toplam baskınlık sayısı fazlayken bir başka bölgenin az olması ya da hiç olmaması genel olarak bu bölgeler arasında gelir eşitsizliğinin arttı̆̆ 1 şeklinde yorumlanabilir. Dolayısıyla en fazla baskınlık alan bölgeler ile hiç baskınlık alamayan bölgeler arasında daha büyük boyutta gelir dağılımı eşitsizliğinden söz edilebilir. Tablo 5 'te elde edilen toplamlara dayalı değerler SSD kriterinin genel olarak Gini ve yüzde paylar ile benzer doğrultuda sonuçlar verdiğini göstermektedir.

\section{SONUÇ}

Gelir dağılımındaki eşitsizlik ülkeler arası bir sorun olmasının yanında bir ülkenin bölgeleri arasında da oluşan bir problem olarak karşımıza çıkmaktadır. Ülkemizde de araştırma sonuçlarından elde edilerek yayınlanan istatistiklerden anlaşılabileceği gibi yüksek seviyelerde gelir farklılıklarının neden çözümlenmesi gereken problem olarak görüldüğü alında aşikardır. Türkiye'de TÜİK tarafindan raporlanan Gini katsayısı ve yüzdelik paylar bölgeler arası gelir eşitsizliğinin varlı̆̆ını ortaya koymaktadır. Ancak nüfus yoğunluğu açısından bakıldığında genellikle kullanılan \%5'lik gruplarla analiz gelir dağılımlarına ilişkin özet bilgi niteliğinde kalmaktadır. Her bir bölge için özet olarak sunulmuş bir bilginin bölgelerarası karşılaştırmalarda kullanılması yanıltıc1 sonuçlar verebilmektedir. İstatistiksel dağılımın teorisine ilişkin varsayımları göz ardı edebilen ve Genelleştirilmiş Lorenz eğrisi ile eşdeğer olduğu bilinen SSD kriteri bölgelerarası gelir dağılımı karşılaştırmalarında ayrıntılı analizi mümkün kılmaktadır.

Çalışmanın sonuçlarına göre, en fazla sayıda baskınlığı olan İstanbul (TR1)'da herhangi bir ferdin elde ettiği gelir ve daha düşük gelir düzeylerine sahip olanların ortalaması, bir başka bölgede aynı gelir düzeyine denk gelen fertlere eşit veya daha fazladır. İstanbul (TR1)'dan sonra en fazla baskınlık alan bölge Doğu Karadeniz (TR9)'dir. En az sayıda baskınlık alan bölgeler ise Ege (TR3), Akdeniz (TR6) ve Güney Doğu Anadolu (TRC)'dir. Güney Doğu Anadolu (TRC) bölgesi hiçbir bölgeye göre baskınlık alamayan bölgedir. 2012, 2013 ve 2014 yıllarında tüm bölgelere SSD kriterine göre baskınlık alan Doğu Karadeniz (TR9), Gini katsayısı ve yüzde paylar değerlerindeki farklılığıyla da ön plana çıkan bir bölgedir. 2006-2017 yılları arasında Doğu Karadeniz (TR9)'in gelir dağılımına baskınlık sağlayan hiçbir bölge gelir dağılımı olamamıştır. Doğu Karadeniz (TR9) sergilediği bu sonuçlarla özel olarak incelenmesi gereken bir bölgedir.

Bulgular kısmında ele alınan değerler göstermektedir ki bir bölgenin Gini katsayısı yıllara göre arttığında diğer bölgelerin gelir dağılımlarına göre baskınlık sayılarında azalma gözlenebilmektedir. Tersine Gini katsayısı yıllara göre azaldığında ilgili bölgenin aldığı baskınlık sayısında da artış gözlendiği söylenebilmektedir. Çalışmada elde edilen bulgulara göre 
bir bölgedeki Gini katsayısının bir başka bölgeden daha düşük bir değer olması, gelir dağılımının daha baskın olduğu anlamını taşımamaktadır. Ancak, Gini katsayısının yüksek değerler aldığı bölgeler SSD kriteri ile baskınlık sayıları da az olan bölgeler olmuştur. SSD kriteri diğer katsayılara göre bölgeler arası karşılaştırmaları daha ayrıntılı kılmaktadır.

Sonuçlar araştırmacılara ve yöneticilere gelir eşitsizliği ile ilgili bölgeler arası veya bölgelere özel politikalar geliştirilmesi için yol gösterici niteliktedir. Bu politikaların neler olabileceğine dair sonuçlar elbette ki ilgili yıllara ait ekonomik gelişmelerle birlikte incelendiğinde daha fazla anlam kazanabilecektir. Türkiye'de bölgeler arası gelir dağılımının incelendiği diğer çalışmalarda da belirtildiği gibi gelirin yeniden dağılımını sağlayan politikalar, örneğin istihdam, işsizlik, yoksulluk ve bölgelerarası göç, eğitimde firsat eşitliği, bölgelerin coğrafi özelliklerine uygun sektörlerin gelişimi ve nüfus planlaması gibi unsurlara ağırlık verilmesi, şüphesiz ki bölgelerarası bireysel gelir eşitsizliğinin azaltılmasında etkili olacaktır. Ayrıca bölgelere göre gelişmişlik düzeylerindeki farklılıklar da gelir eşitsizliği sorununu ortaya çıkarmaktadır.

Bu çalışma, literatürde yapılan pek çok çalışma arasında, Türkiye'de bölgelerarası gelir dağılımı eşitsizliğinin değerlendirilmesinde SSD kriterinden de faydalanılabileceğini ayrıntılı olarak göstermeyi amaçlayan ilk çalışma niteliğindedir. Sonuçlar son yıllarda aynı veri dönemini ele alan ve bölgesel gelir eşitsizliğini inceleyen çalışmalarla da örtüşmektedir (Tahsin, 2019; Şık ve Öztürk, 2019; Topuz ve Sekmen 2020). SSD gelir dağılımı açısından en adaletli bölgeyi direk işaret etmese de hiçbir bölgeye baskınlığ olmayan ve aynı zamanda hiçbir bölgenin üzerinde baskın olamadığı gelir dağılımlarına sahip bölgeler gelir dağılımı açısından daha adaletli bölgeler olarak görülebilir. SSD hangi iki bölge veya bölgeler arasında gelir eşitsizliği olduğunu, gerek baskın olduğu bölgeyi direk göstererek gerekse sağladığı baskınlık sayısı açısından Gini katsayısı ve yüzdelik paylara göre daha açık olarak ifade edebilmektedir. Bu sonuç çalışmanın analizinde Gini katsayısı veya yüzdelik paylar açısından eşit olan ancak, SSD kriteri açısından farklı1ıkları ortaya koyulabilen bölgesel gelir dağılımı karşılaştırılmalarından açıkça görülebilmektedir. $\mathrm{Bu}$ nedenle SSD kriteri bölgelerin gelir dağılımlarına ilişkin tanımsal istatistiklere ve belirli katsayılara göre daha derinlemesine analiz imkânı sağlamaktadır.

Şüphesiz ki gelir eşitsizliği gibi tüm dünyada problem olarak ele alınan bu konu üzerinde araştırılması gereken etken ve değişkenler oldukça fazladır. Belirli sayısal yaklaşımlarla probleme 1şık tutmayı amaçlayan çalışmaların yanında gelir eşitsizliğine sebep olan ekonomik, coğrafi, sosyal ve beşerî sebeplerin araştırılması da çözüme esas katkıyı sağlayacaktır. Yeni modeller ve analizlerle bu değişkenler ayrıntılı olarak ele alınmalıdır. Dolayısıyla, özellikle SSD kriterinin bölgesel gelir eşitsizliği analizinde kullanımını ele alan bu sayısal çalışma zenginleştirilmeye de açıktır.

\section{Araştırma ve Yayın Etiği Beyanı}

$\mathrm{Bu}$ çalışma bilimsel araştırma ve yayın etiği kurallarına uygun olarak hazırlanmıştır.

\section{Yazarların Makaleye Katkı Oranları}

Yazarın çalışmaya katkısı \%100’dür.

\section{Çıkar Beyanı}

Yazar açısından ya da üçüncü taraflar açısından çalışmadan kaynaklı çıkar çatışması bulunmamaktadır. 


\section{KAYNAKÇA}

Acar, İ. (2015), Türkiye'de gelir dağılımı, Hak-İş Uluslararası Emek ve Toplum Dergisi, 4(8), 42-59.

Alabaş, M. M. (2015). Türkiye'de Bölgesel düzeyde gelir dağılımı eşitsizliğinin incelenmesi. IV. Türkiye Lisansüstü Çalışmalar Kongresi Bildiriler Kitabı II, 255-271.

Anderson, G. (1996). Nonparametric tests of stochastic dominance in income distributions. Econometrica: Journal of the Econometric Society, 1183-1193.

Aran, M., Demir, S., Sarıca, Ö. \& Yazıc1, H. (2010). Poverty and inequality changes in Turkey (2003-2006). Ankara, Türkiye: World Bank. [Available online at: http://hdl.handle.net/10986/27836.]. Erişim Tarihi: 12.03.2020.

Atkinson, A.B. (1970). On the measurement of inequality. Journal of Economic Theory, 2, 244-263.

Bishop, J. A., Chakraborti, S. \& Thistle, P. D. (1989). Asymptotically distribution-free statistical inference for generalized Lorenz curves. The Review of Economics and Statistics, 725-727.

Bishop, J. A., Formby, J. P. \& Smith, W. J. (1991). International comparisons of income inequality: Tests for Lorenz dominance across nine countries. Economica, 461-477.

Bozkurt, E., Altıner, A., \& Topçuoğlu, Ö. (2020). Türkiye'de Doğrudan Yabancı Sermaye Yatırımlarının Gelir Eşitsizliği Perspektifinden Analizi. Siyaset, Ekonomi ve Yönetim Araştırmaları Dergisi, 8(2), 79-97.

Bozma, K. A., Bozma, G., \& Güney, A. Enflasyon ve işsizliğin yoksulluk üzerindeki etkisi: Türkiye Düzey-1 bölgeleri örneği. Kafkas Üniversitesi İktisadi ve İdari Bilimler Fakültesi Dergisi, 11(22), 973-996.

Coşkun, M. N. (2012). Türkiye'de Yoksulluk: Bölgesel Farklllıklar ve Yoksulluğun Profili (No. 2012/59). Discussion Paper. Ankara, Türkiye: Turkish Economic Association. [Çevrim-içi: http://www.tek.org.tr/files/disc/dt115.pdf]. Erişim Tarihi: 12.03.2020.

Dasgupta, P., Sen, A. \& Starrett, D. (1973). Notes on the measurement of inequality. Journal of economic theory, 6(2), 180-187.

Davidson, R. \& Duclos J.Y. (2000). Statistical inference for stochastic dominance and for the measurement of poverty and inequality. Econometrica, 68(6), 1435-1464.

Doğanoğlu, F., \& Gülcü, A. (2001). Gelir eşitsizliği ölçümünde kullanilan yöntemler. Cumhuriyet Üniversitesi, Iktisadi ve İdari Bilimler Dergisi, 2(1), 47-65.

Dorfman, R. (1979). A formula for the Gini coefficient. The review of economics and statistics, 146-149.

Ersungur, Ş. M. \& Polat, Ö. (2006). Türkiye'de bölgeler arasında yakınsama analizi. Atatürk Üniversitesi Sosyal Bilimler Enstitüsü Dergisi, 8(2), 335-343.

Ferreira, F. H. \& Litchfield, J. (1996). Growing apart: inequality and poverty trends in Brazil in the 1980s. LSE STICERD Research Paper, (23). [Available online at: https://papers.ssrn.com/sol3/papers.cfm?abstract_id=1094768 ]. Retrieved on January 15, 2020.

Filiztekin, A. \& Çelik, M. A. (2010). Türkiye'de bölgesel gelir eşitsizliği (Regional income inequality in Turkey). Megaron, 5(3), 116-127.

Filiztekin, A. (2020). Income Inequality in Turkey: 2003-2015. In Turkey's Political Economy in the 21st Century, Palgrave Macmillan, Cham, 63-84.

Foster, J. E. \& Shorrocks, A. F. (1988). Poverty orderings. Econometrica: Journal of the Econometric Society, 173177.

Giorgi, G. M. \& Gigliarano, C. (2017). The Gini concentration index: a review of the inference literature. Journal of Economic Surveys, 31(4), 1130-1148.

Hadar, J. \& Russell, W. R. (1969). Rules for ordering uncertain prospects. The American Economic Review, 25-34.

Hanoch, G. \& Levy, H. (1969). The efficiency analysis of choices involving risk. The Review of Economic Studies, $36(3), 335-346$.

Hepaktan, E. \& Alkaya A. (2001), Türkiye'de gelir dağılımının bölgesel yönden incelenmesi, Yönetim ve Ekonomi, $8(2), 39-54$.

Karaca, O. (2004), Türkiye'de bölgeler arası gelir farklılıkları: yakınsama var mı?, Türkiye Ekonomi Kurumu Tartışma Metni, 2004/7. 
Karaca, O. (2018), Türkiye'de Bölgesel Yakınsamanın 50 Yılı: Yeni Veri Seti ve 1960-2010 Dönemi Analizi, Sosyoekonomi, Vol. 26(35), 207-228.

Kuştepeli, Y. R. \& Halaç, U. (2004). Türkiye'de genel gelir dağılımının analizi ve iyileştirilmesi, Dokuz Eylül Üniversitesi Sosyal Bilimler Enstitüsü Dergisi, 6(4).

Le Breton, M., Michelangeli, A. \& Peluso, E. (2012). A stochastic dominance approach to the measurement of discrimination. Journal of Economic Theory, 147(4), 1342-1350.

Lorenz, M.O. (1905). Methods of measuring the concentration of wealth. Quarterly Publications of the American Statistical Association, 9 (New Series, No. 70), 209-219.

Maasoumi, E. \& Heshmati, A. (2000). Stochastic dominance amongst Swedish income distributions. Econometric Reviews, 19(3), 287-320.

Mehdi, T. (2019). Stochastic dominance approach to OECD's Better Life Index. Social Indicators Research, 143(3), 917-954.

Mehdi, T. (2020). Testing for stochastic dominance up to a common relative poverty line. Econometrics, 8(1), 5.

Nal, M. (2019). Türkiye'de bölgesel gelir dengesizliği: işgücü başına geliryakınsaması. Hitit Üniversitesi Sosyal Bilimler Enstitüsü Dergisi, 12(2), 469-480. doi: 10.17218/hititsosbil.632654.

Özdemir, M. Ç. (2019). Özellikli objektif gelir eşitsizliği ölçüm yöntemleri üzerine değerlendirmeler. Sakarya Üniversitesi Çalışma Ekonomisi ve Endüstri İlişkileri Seçme Yazılar-III, $35 . \quad$ [Çevrim-içi: https://ceko.sakarya.edu.tr/en/icerik/17557/91339/select-articles], Erişim Tarihi: 2.01.2020.

Öztürk, L. (2005), Bölgelerarası gelir eşitsizliği: istatistiki bölge birimleri sınıflandırması'na (İBBS) göre eşitsizlik indeksleri ile bir analizi, 1965-2001, Akdeniz I.I. B.F. Dergisi, 95-110.

Quirk, J. P. \& Saposnik, R. (1962). Admissibility and measurable utility functions. The Review of Economic Studies, 29(2), 140-146.

Rothschild, M. \& Stiglitz, J. E. (1973). Some further results on the measurement of inequality. Journal of Economic Theory, 6(2), 188-204.

Sen, A. (1973). Poverty, inequality and unemployment: Some conceptual issues in measurement. Economic and Political Weekly, 1457-1464.

Shorrocks, A. F. (1983). Ranking income distributions. Economica, 50(197), 3-17.

Şenesen, Ü. (2003). Bölgesel gelir dağılımı. Balkan, N. Ve Savran, S. (Ed.), Neoliberalizmin Tahribati (127-138). İstanbul : Metis Yayınları.

Şık, A. \& Öztürk, Z. (2019). Türkiye'de bölgesel gelir eşitsizliğinin nedenleri: bölgeler arası bir karşılaştırma. Gözen, M. Ç. ve Soylu Ö. B. (Ed.), Dünden Bugüne Ekonomi Yazıları III (41-54), İzmit: Umuttepe Yayınları.

Tahsin, E. (2019). An investigation of the Palma Ratio for Turkey both on national and regional level. Sosyoekonomi, 27(41), 151-182.

Thistle, P. D. (1989). Ranking distributions with generalized Lorenz curves. Southern Economic Journal, 1-12.

Topuz, S. G., \& Sekmen, T. Türkiye'de Hanehalkı Gelir Eşitsizliğine Etki Eden Faktörlerin Lorenz ve Yoğunlaşma Eğrileri ile Analiz Edilmesi ve Bölgeler Arası Karşılaştırma. Current Research in Social Sciences, 6(2), 103-124.

Totaktlığlu, İ. \& Atan, M. (2007). Türkiye'de bölgeler arası gelişmişlik düzeyi ve gelir dağılımı eşitsizliği: Kuznets eğrisi geçerli mi?. Ekonomik Yaklaşım, 18(65), 25-58.

TÜIKK, 2018. Gelir Dağılımı ve Yaşam Koşulları İstatistikleri, [Çevrim-içi: http://www.tuik.gov.tr], Erişim Tarihi: 26.10.2018.

Yamak, R. \& Yamak N. (1999), Türkiye'de gelir dağılımı ve iç göç, Dokuz Eylül Üniversitesi Sosyal Bilimler Enstitüsü Dergisi, 1(1), 16-28.

Yitzhaki, S. (1982). Stochastic dominance, mean variance, and Gini's mean difference. The American Economic Review, 72(1), 178-185.

Yitzhaki, S. (1983). On an extension of the Gini index of inequality. International Economic Review, 24(3), 617-628. 


\section{Extended Summary}

\section{Regional Evaluation of Individual Income Distribution in Turkey with Stochastic Dominance Criteria}

In Turkey as well as in other countries, income inequality is a problem that governments always need to work on. The indicators, for reasons such as economic conditions and country policies reveal income inequality in world countries. As in the rest of the world, income inequality problem arises in our country for reasons such as differences in development levels by regions. Work on the topic that income inequality between regions in Turkey has increased, especially after the 2000s (Yamak ve Yamak, 1999; Hepaktan ve Alkaya, 2001; Şenesen, 2003; Karaca, 2004; Kuştepeli ve Halaç, 2004; Öztürk, 2005; Ersungur ve Polat, 2006; Tokatlığlu ve Atan, 2007; Filiztekin ve Çelik, 2010; Coşkun, 2012; Acar, 2015; Alabaş, 2015; Şık ve Öztürk, 2019; Nal, 2019; Özdemir, 2019; Bozma, Bozma ve Güney, 2020; Topuz ve Sekmen, 2020).

Income is the sum of the value of goods and services recreated in a specific period in a national economy. This is also called total revenue. Income for the household or individual can be defined as the sum of the values obtained in a certain period in return for the contribution made to production. Household income can be also rent, interest, or profit in addition to wages and salaries for labor. Income Distribution is the division of income generated in a country over certain periods between individuals, households or production factors.

Gini coefficient reported by TUIK within 12 regions reveals the existence of income inequality between regions in Turkey. Information on income distribution is also provided through quartiles belonging to 20 subgroups with only 5\%, but when considered in terms of population density, it remains as summary information regarding income distributions, such as the Gini coefficient. Especially after the 1970s, the Gini coefficient has been criticized for the insufficiency of the useful information it provides (Atkinson, 1970; Sen, 1973).

One of the most common approaches used for income distribution analysis is the Lorenz Curve and the Gini coefficient calculated on this curve. As another nonparametric approach, stochastic dominance provides different interpretation opportunities for comparison between income distributions. While the second order stochastic dominance criterion is a term mostly used in finance, Lorenz Curve is used in the analysis of income distribution inequality. The Lorenz curve is also a graphical representation of the cumulative income distribution. Thistle (1989) showed that Generalized Lorenz curve and second order stochastic dominance criteria are equivalent each other's. As a distribution-free decision rule, stochastic dominance takes into account the entire distribution of return rather than some specific characteristic, such as variance.

Let's consider for all real numbers $x(x \in \mathcal{R})$, probability function $f(x)$ and their cumulative distribution fucntion as $F(x)=\int_{-\infty}^{x} f(t) d t$. For random variable $x$ and its threshold value $\eta$ second order stochastic dominance criteria is given by

$$
\boldsymbol{E}\left([\boldsymbol{\eta}-\boldsymbol{f}]_{+}\right) \leq \boldsymbol{E}\left([\boldsymbol{\eta}-\boldsymbol{g}]_{+}\right)
$$

where $[\eta-f]_{+}=\max (0, \eta-f)$. This is also interpreted as the $\mathrm{f}$ distribution as more predictable or less risky than the g distribution. Atkinson (1970) applies second order stochastic dominance by taking advantage of the characteristics of continuous distributions to compare income distributions.

In order to be discovered in terms of regional income distribution in Turkey, the Turkey Statistics Institute Survey of Income and Living Conditions survey years 2007-2016 were used. The demographic information of household members aged 15 and over is taken into account at 
Level 1 according to the Statistical Region Units Classification (NUTS). Comparisons were made by means of stochastic dominance criterion in the period considered among 12 sub-regions according to NUTS-Level 1. For the comparisons, the total value of the income obtained by the individual in the reference year from the cross section of the equivalent household disposable income was used. The reference period for income information has been specified as the previous calendar year. Therefore, for example, the income information presented in 2007 in the study covers the period between January-December 2006. As the purchasing power of individuals may differ between regions according to living conditions, incomes have been rearranged according to the Consumer Spending Price Index (THFE).

According to the comparison of individual income distributions among regions, while the regions that provide the highest number of dominance are Istanbul and East Blacksea, it is seen that the South East Anatolia region is the region that cannot second order stochastically dominate any region. The results included in the tables for the years 2007-2016 allow for the comparison, examination and interpretation of the regions in pairs and. Moreover, the results contain information that supports the interpretation that the Gini coefficient causes information loss regarding to income distributions. For other regions, the values that can be interpreted individually and discussed in the findings part of our study show that the results obtained through the second order stochastic dominance criterion are more explanatory than the Gini coefficient, although not in the same direction with the Gini coefficient. The results obtained are considered to be evaluable in the policy development process by regions. 
EK. İBBS Düzey-1'e göre bölgelerin 2008-2015 arası karşılaştırmaları

Tablo 6: 2008 Yılına Ait Karşılaştırmalar

\begin{tabular}{lcccccccccccc} 
2008 & TR1 & TR2 & TR3 & TR4 & TR5 & TR6 & TR7 & TR8 & TR9 & TRA & TRB & TRC \\
\hline TR1 & 0 & 691 & 1000 & 333 & 546 & 1000 & 326 & 1000 & 333 & 761 & 1000 & 1000 \\
TR2 & 309 & 0 & 995 & 0 & 0 & 1000 & 0 & 901 & 0 & 640 & 810 & 988 \\
TR3 & 0 & 5 & 0 & 0 & 0 & 368 & 0 & 2 & 0 & 30 & 0 & 882 \\
TR4 & 667 & 1000 & 1000 & 0 & 941 & 1000 & 0 & 1000 & 201 & 959 & 978 & 1000 \\
TR5 & 454 & 1000 & 1000 & 59 & 0 & 1000 & 0 & 1000 & 3 & 881 & 977 & 1000 \\
TR6 & 0 & 0 & 632 & 0 & 0 & 0 & 0 & 2 & 0 & 28 & 0 & 873 \\
TR7 & 674 & 1000 & 1000 & 1000 & 1000 & 1000 & 0 & 1000 & 318 & 999 & 1000 & 1000 \\
TR8 & 0 & 99 & 998 & 0 & 0 & 998 & 0 & 0 & 0 & 238 & 717 & 998 \\
TR9 & 667 & 1000 & 1000 & 799 & 997 & 1000 & 682 & 1000 & 0 & 1000 & 999 & 1000 \\
TRA & 239 & 360 & 970 & 41 & 119 & 972 & 1 & 762 & 0 & 0 & 949 & 970 \\
TRB & 0 & 190 & 1000 & 22 & 23 & 1000 & 0 & 283 & 1 & 51 & 0 & 1000 \\
TRC & 0 & 12 & 118 & 0 & 0 & 127 & 0 & 2 & 0 & 30 & 0 & 0 \\
\hline
\end{tabular}

Tablo 7: 2009 Yılına Ait Karşılaştırmalar

\begin{tabular}{lcccccccccccc} 
2009 & TR1 & TR2 & TR3 & TR4 & TR5 & TR6 & TR7 & TR8 & TR9 & TRA & TRB & TRC \\
\hline TR1 & 0 & 510 & 1000 & 343 & 340 & 1000 & 444 & 607 & 324 & 834 & 999 & 1000 \\
TR2 & 489 & 0 & 1000 & 82 & 0 & 933 & 256 & 1000 & 25 & 944 & 848 & 1000 \\
TR3 & 0 & 0 & 0 & 0 & 0 & 339 & 0 & 149 & 5 & 223 & 312 & 1000 \\
TR4 & 656 & 897 & 1000 & 0 & 418 & 1000 & 958 & 1000 & 278 & 1000 & 979 & 1000 \\
TR5 & 659 & 990 & 1000 & 572 & 0 & 1000 & 990 & 1000 & 301 & 1000 & 990 & 1000 \\
TR6 & 0 & 67 & 661 & 0 & 0 & 0 & 0 & 138 & 36 & 102 & 333 & 1000 \\
TR7 & 555 & 724 & 1000 & 22 & 0 & 1000 & 0 & 1000 & 79 & 1000 & 980 & 1000 \\
TR8 & 393 & 0 & 851 & 0 & 0 & 862 & 0 & 0 & 0 & 835 & 836 & 999 \\
TR9 & 675 & 946 & 995 & 701 & 689 & 964 & 901 & 1000 & 0 & 1000 & 938 & 1000 \\
TRA & 166 & 56 & 777 & 0 & 0 & 898 & 0 & 165 & 0 & 0 & 848 & 1000 \\
TRB & 0 & 123 & 688 & 0 & 0 & 667 & 0 & 164 & 33 & 152 & 0 & 1000 \\
TRC & 0 & 0 & 0 & 0 & 0 & 0 & 0 & 1 & 0 & 0 & 0 & 0 \\
\hline
\end{tabular}

Tablo 8: 2010 Yılına Ait Karşılaştırmalar

\begin{tabular}{lcccccccccccc} 
2010 & TR1 & TR2 & TR3 & TR4 & TR5 & TR6 & TR7 & TR8 & TR9 & TRA & TRB & TRC \\
\hline TR1 & 0 & 370 & 1000 & 301 & 277 & 969 & 441 & 455 & 322 & 734 & 1000 & 1000 \\
TR2 & 630 & 0 & 1000 & 283 & 423 & 972 & 922 & 973 & 90 & 1000 & 973 & 1000 \\
TR3 & 0 & 0 & 0 & 0 & 0 & 297 & 0 & 56 & 0 & 192 & 568 & 936 \\
TR4 & 699 & 702 & 1000 & 0 & 722 & 985 & 971 & 882 & 369 & 1000 & 985 & 1000 \\
TR5 & 723 & 561 & 1000 & 263 & 0 & 984 & 926 & 864 & 368 & 1000 & 984 & 1000 \\
TR6 & 31 & 3 & 703 & 0 & 0 & 0 & 0 & 77 & 34 & 234 & 975 & 1000 \\
TR7 & 559 & 62 & 1000 & 14 & 58 & 984 & 0 & 474 & 83 & 1000 & 984 & 1000 \\
TR8 & 545 & 0 & 944 & 103 & 120 & 898 & 510 & 0 & 4 & 856 & 957 & 950 \\
TR9 & 678 & 883 & 1000 & 616 & 616 & 941 & 901 & 953 & 0 & 946 & 955 & 986 \\
TRA & 266 & 0 & 808 & 0 & 0 & 766 & 0 & 144 & 54 & 0 & 968 & 1000 \\
TRB & 0 & 0 & 432 & 0 & 0 & 0 & 0 & 0 & 0 & 32 & 0 & 882 \\
TRC & 0 & 0 & 64 & 0 & 0 & 0 & 0 & 50 & 14 & 0 & 118 & 0 \\
\hline
\end{tabular}


Tablo 9: 2011 Yılına Ait Karşılaştırmalar

\begin{tabular}{ccccccccccccc} 
2011 & TR1 & TR2 & TR3 & TR4 & TR5 & TR6 & TR7 & TR8 & TR9 & TRA & TRB & TRC \\
\hline TR1 & 0 & 352 & 1000 & 517 & 407 & 999 & 404 & 461 & 206 & 809 & 999 & 1000 \\
TR2 & 648 & 0 & 958 & 937 & 696 & 964 & 790 & 967 & 70 & 879 & 967 & 967 \\
TR3 & 0 & 42 & 0 & 0 & 0 & 634 & 0 & 46 & 65 & 0 & 581 & 973 \\
TR4 & 482 & 63 & 1000 & 0 & 0 & 980 & 0 & 119 & 69 & 848 & 980 & 1000 \\
TR5 & 592 & 304 & 1000 & 992 & 0 & 992 & 318 & 793 & 79 & 992 & 992 & 1000 \\
TR6 & 0 & 36 & 366 & 0 & 0 & 0 & 0 & 32 & 62 & 0 & 398 & 983 \\
TR7 & 595 & 210 & 1000 & 987 & 674 & 987 & 0 & 987 & 81 & 987 & 987 & 1000 \\
TR8 & 538 & 33 & 954 & 861 & 199 & 943 & 0 & 0 & 63 & 842 & 957 & 982 \\
TR9 & 794 & 930 & 935 & 931 & 921 & 938 & 919 & 937 & 0 & 922 & 938 & 939 \\
TRA & 190 & 121 & 1000 & 132 & 0 & 979 & 0 & 137 & 78 & 0 & 979 & 1000 \\
TRB & 0 & 33 & 419 & 0 & 0 & 577 & 0 & 12 & 62 & 0 & 0 & 985 \\
TRC & 0 & 33 & 27 & 0 & 0 & 17 & 0 & 18 & 61 & 0 & 15 & 0 \\
\hline
\end{tabular}

Tablo 10: 2012 Yılına Ait Karşılaştırmalar

\begin{tabular}{ccccccccccccc} 
2012 & TR1 & TR2 & TR3 & TR4 & TR5 & TR6 & TR7 & TR8 & TR9 & TRA & TRB & TRC \\
\hline TR1 & 0 & 304 & 1000 & 624 & 280 & 1000 & 352 & 676 & 0 & 999 & 1000 & 1000 \\
TR2 & 696 & 0 & 1000 & 1000 & 756 & 1000 & 871 & 1000 & 0 & 997 & 991 & 1000 \\
TR3 & 0 & 0 & 0 & 0 & 0 & 960 & 0 & 14 & 0 & 0 & 321 & 899 \\
TR4 & 376 & 0 & 1000 & 0 & 14 & 1000 & 0 & 755 & 0 & 894 & 912 & 997 \\
TR5 & 720 & 244 & 1000 & 986 & 0 & 1000 & 375 & 1000 & 0 & 934 & 944 & 989 \\
TR6 & 0 & 0 & 40 & 0 & 0 & 0 & 0 & 21 & 0 & 0 & 4 & 857 \\
TR7 & 648 & 129 & 1000 & 1000 & 625 & 1000 & 0 & 1000 & 0 & 1000 & 1000 & 1000 \\
TR8 & 324 & 0 & 986 & 245 & 0 & 979 & 0 & 0 & 0 & 884 & 902 & 969 \\
TR9 & 1000 & 1000 & 1000 & 1000 & 1000 & 1000 & 1000 & 1000 & 0 & 1000 & 1000 & 1000 \\
TRA & 1 & 3 & 1000 & 106 & 66 & 1000 & 0 & 116 & 0 & 0 & 960 & 1000 \\
TRB & 0 & 9 & 679 & 88 & 56 & 996 & 0 & 98 & 0 & 40 & 0 & 995 \\
TRC & 0 & 0 & 101 & 3 & 11 & 143 & 0 & 31 & 0 & 0 & 5 & 0 \\
\hline
\end{tabular}

Tablo 11: 2013 Yılına Ait Karşılaştırmalar

\begin{tabular}{ccccccccccccc} 
2013 & TR1 & TR2 & TR3 & TR4 & TR5 & TR6 & TR7 & TR8 & TR9 & TRA & TRB & TRC \\
\hline TR1 & 0 & 273 & 1000 & 1000 & 549 & 1000 & 481 & 1000 & 0 & 1000 & 1000 & 1000 \\
TR2 & 727 & 0 & 1000 & 1000 & 1000 & 1000 & 1000 & 1000 & 0 & 1000 & 979 & 1000 \\
TR3 & 0 & 0 & 0 & 0 & 0 & 927 & 0 & 0 & 0 & 29 & 6 & 902 \\
TR4 & 0 & 0 & 1000 & 0 & 0 & 992 & 6 & 830 & 0 & 846 & 844 & 939 \\
TR5 & 451 & 0 & 1000 & 1000 & 0 & 1000 & 299 & 1000 & 0 & 962 & 918 & 982 \\
TR6 & 0 & 0 & 73 & 8 & 0 & 0 & 7 & 0 & 0 & 28 & 9 & 813 \\
TR7 & 519 & 0 & 1000 & 994 & 701 & 993 & 0 & 978 & 0 & 1000 & 951 & 978 \\
TR8 & 0 & 0 & 1000 & 170 & 0 & 1000 & 22 & 0 & 0 & 761 & 859 & 975 \\
TR9 & 1000 & 1000 & 1000 & 1000 & 1000 & 1000 & 1000 & 1000 & 0 & 1000 & 1000 & 1000 \\
TRA & 0 & 0 & 971 & 154 & 38 & 972 & 0 & 239 & 0 & 0 & 598 & 963 \\
TRB & 0 & 21 & 994 & 156 & 82 & 991 & 49 & 141 & 0 & 402 & 0 & 985 \\
TRC & 0 & 0 & 98 & 61 & 18 & 187 & 22 & 25 & 0 & 37 & 15 & 0 \\
\hline
\end{tabular}


Tablo 12: 2014 Yılına Ait Karşılaş̧tırmalar

\begin{tabular}{ccccccccccccc} 
2014 & TR1 & TR2 & TR3 & TR4 & TR5 & TR6 & TR7 & TR8 & TR9 & TRA & TRB & TRC \\
\hline TR1 & 0 & 218 & 1000 & 1000 & 847 & 1000 & 612 & 1000 & 0 & 971 & 1000 & 1000 \\
TR2 & 782 & 0 & 1000 & 1000 & 993 & 1000 & 1000 & 992 & 0 & 943 & 991 & 997 \\
TR3 & 0 & 0 & 0 & 41 & 0 & 781 & 17 & 0 & 0 & 0 & 0 & 891 \\
TR4 & 0 & 0 & 959 & 0 & 0 & 959 & 16 & 760 & 0 & 295 & 849 & 933 \\
TR5 & 153 & 7 & 1000 & 1000 & 0 & 1000 & 137 & 928 & 0 & 842 & 907 & 989 \\
TR6 & 0 & 0 & 219 & 41 & 0 & 0 & 20 & 0 & 0 & 0 & 1 & 822 \\
TR7 & 388 & 0 & 983 & 984 & 863 & 980 & 0 & 949 & 0 & 851 & 919 & 973 \\
TR8 & 0 & 8 & 1000 & 240 & 72 & 1000 & 51 & 0 & 0 & 156 & 892 & 1000 \\
TR9 & 1000 & 1000 & 1000 & 1000 & 1000 & 1000 & 1000 & 1000 & 0 & 1000 & 1000 & 1000 \\
TRA & 29 & 57 & 1000 & 705 & 158 & 1000 & 149 & 844 & 0 & 0 & 1000 & 1000 \\
TRB & 0 & 9 & 1000 & 151 & 93 & 999 & 81 & 108 & 0 & 0 & 0 & 999 \\
TRC & 0 & 3 & 109 & 67 & 11 & 178 & 27 & 0 & 0 & 0 & 1 & 0 \\
\hline
\end{tabular}

Tablo 13: 2015 Yılına Ait Karşılaştırmalar

\begin{tabular}{ccccccccccccc} 
2015 & TR1 & TR2 & TR3 & TR4 & TR5 & TR6 & TR7 & TR8 & TR9 & TRA & TRB & TRC \\
\hline TR1 & 0 & 222 & 1000 & 1000 & 726 & 1000 & 246 & 1000 & 16 & 656 & 1000 & 1000 \\
TR2 & 778 & 0 & 929 & 894 & 855 & 931 & 804 & 916 & 0 & 859 & 902 & 926 \\
TR3 & 0 & 71 & 0 & 12 & 0 & 668 & 13 & 38 & 14 & 0 & 30 & 943 \\
TR4 & 0 & 106 & 988 & 0 & 0 & 1000 & 14 & 1000 & 14 & 280 & 948 & 1000 \\
TR5 & 274 & 145 & 1000 & 1000 & 0 & 1000 & 25 & 1000 & 14 & 625 & 976 & 1000 \\
TR6 & 0 & 69 & 332 & 0 & 0 & 0 & 5 & 34 & 13 & 0 & 28 & 859 \\
TR7 & 754 & 196 & 987 & 986 & 975 & 995 & 0 & 1000 & 14 & 908 & 1000 & 1000 \\
TR8 & 0 & 84 & 962 & 0 & 0 & 966 & 0 & 0 & 7 & 0 & 737 & 959 \\
TR9 & 984 & 1000 & 986 & 986 & 986 & 987 & 986 & 993 & 0 & 981 & 999 & 987 \\
TRA & 344 & 141 & 1000 & 720 & 375 & 1000 & 92 & 1000 & 19 & 0 & 1000 & 1000 \\
TRB & 0 & 98 & 970 & 52 & 24 & 972 & 0 & 263 & 1 & 0 & 0 & 970 \\
TRC & 0 & 74 & 57 & 0 & 0 & 141 & 0 & 41 & 13 & 0 & 30 & 0 \\
\hline
\end{tabular}

Tablo 15: 2016 Yılına Ait Karşılaştırmalar

\begin{tabular}{lcccccccccccc} 
2016 & TR1 & TR2 & TR3 & TR4 & TR5 & TR6 & TR7 & TR8 & TR9 & TRA & TRB & TRC \\
\hline TR1 & 0 & 48 & 1000 & 1000 & 241 & 1000 & 261 & 1000 & 11 & 298 & 598 & 1000 \\
TR2 & 952 & 0 & 985 & 983 & 962 & 987 & 1000 & 989 & 6 & 907 & 898 & 976 \\
TR3 & 0 & 15 & 0 & 4 & 0 & 761 & 27 & 16 & 8 & 0 & 5 & 862 \\
TR4 & 0 & 17 & 996 & 0 & 0 & 998 & 34 & 1000 & 8 & 90 & 5 & 953 \\
TR5 & 759 & 38 & 1000 & 1000 & 0 & 1000 & 278 & 1000 & 11 & 337 & 881 & 1000 \\
TR6 & 0 & 13 & 239 & 2 & 0 & 0 & 24 & 13 & 8 & 0 & 5 & 433 \\
TR7 & 739 & 0 & 973 & 966 & 722 & 976 & 0 & 968 & 0 & 568 & 849 & 963 \\
TR8 & 0 & 11 & 984 & 0 & 0 & 987 & 32 & 0 & 7 & 0 & 0 & 943 \\
TR9 & 989 & 994 & 992 & 992 & 989 & 992 & 1000 & 993 & 0 & 987 & 990 & 990 \\
TRA & 702 & 93 & 1000 & 910 & 663 & 1000 & 432 & 1000 & 13 & 0 & 790 & 1000 \\
TRB & 402 & 102 & 995 & 995 & 119 & 995 & 151 & 1000 & 10 & 210 & 0 & 991 \\
TRC & 0 & 24 & 138 & 47 & 0 & 567 & 37 & 57 & 10 & 0 & 9 & 0 \\
\hline
\end{tabular}

